Prepared in cooperation with the Plains and Prairie Potholes Landscape Conservation Cooperative and the Bureau of Land Management

\title{
Estimating Current and Future Streamflow Characteristics at Ungaged Sites, Central and Eastern Montana, with Application to Evaluating Effects of Climate Change on Fish Populations
}

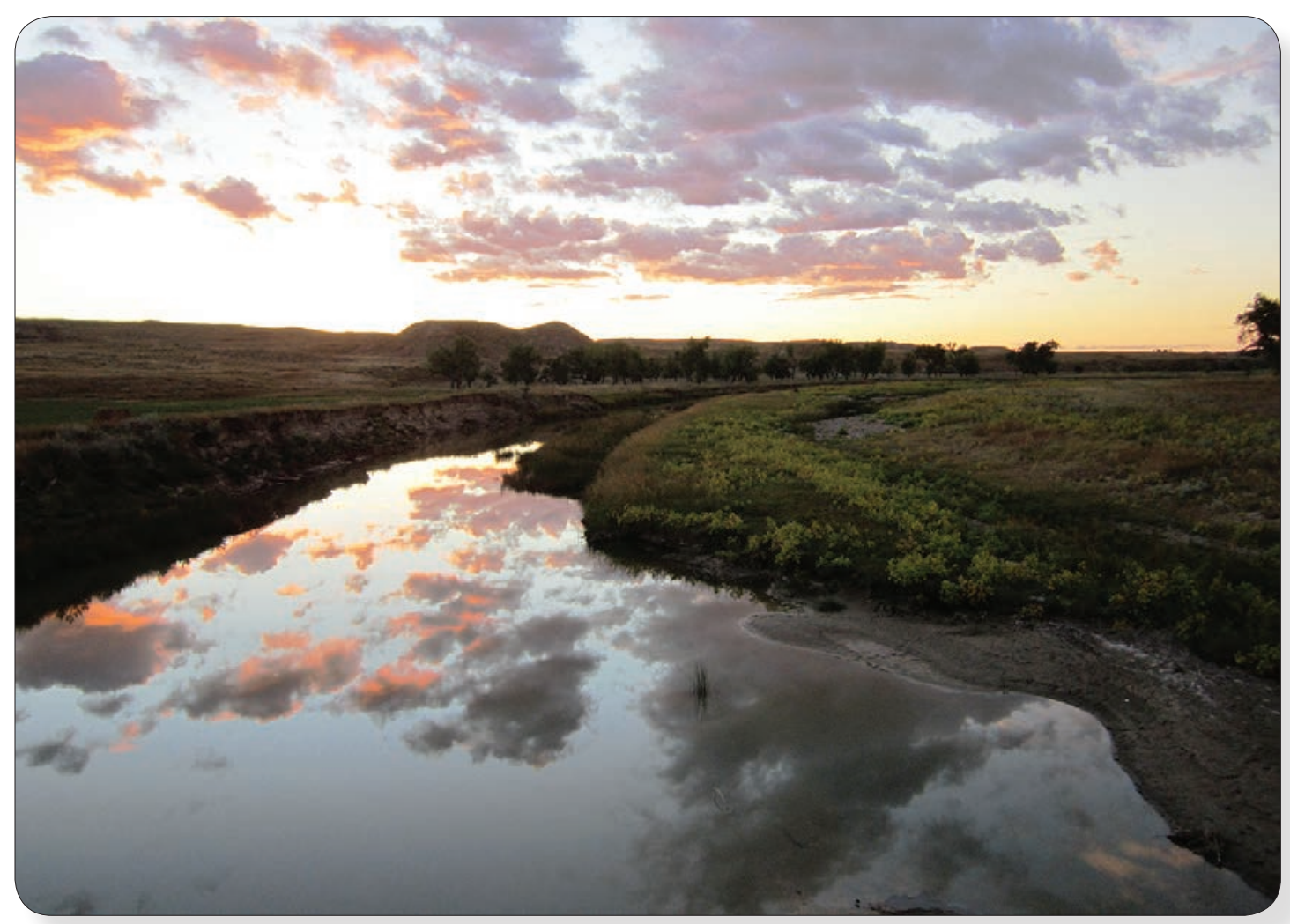

Scientific Investigations Report 2017-5002 
Cover photograph: O'Fallon Creek near Mildred, Montana. Photograph taken by Rod Caldwell, U.S. Geological Survey. 


\section{Estimating Current and Future Streamflow Characteristics at Ungaged Sites, Central and Eastern Montana, with Application to Evaluating Effects of Climate Change on Fish Populations}

By Roy Sando and Katherine J. Chase

Prepared in cooperation with the Plains and Prairie Potholes Landscape

Conservation Cooperative and the Bureau of Land Management

Scientific Investigations Report 2017-5002 


\section{U.S. Department of the Interior SALLY JEWELL, Secretary}

\section{U.S. Geological Survey Suzette M. Kimball, Director}

\section{U.S. Geological Survey, Reston, Virginia: 2017}

For more information on the USGS - the Federal source for science about the Earth, its natural and living resources, natural hazards, and the environment-visit https://www.usgs.gov or call 1-888-ASK-USGS.

For an overview of USGS information products, including maps, imagery, and publications, visit https://store.usgs.gov/.

Any use of trade, firm, or product names is for descriptive purposes only and does not imply endorsement by the U.S. Government.

Although this information product, for the most part, is in the public domain, it also may contain copyrighted materials as noted in the text. Permission to reproduce copyrighted items must be secured from the copyright owner.

Suggested citation:

Sando, Roy, and Chase, K.J., 2017, Estimating current and future streamflow characteristics at ungaged sites, central and eastern Montana, with application to evaluating effects of climate change on fish populations: U.S. Geological Survey Scientific Investigations Report 2017-5002, 23 p., https://doi.org/10.3133/sir20175002.

ISSN 2328-0328 (online) 


\section{Contents}

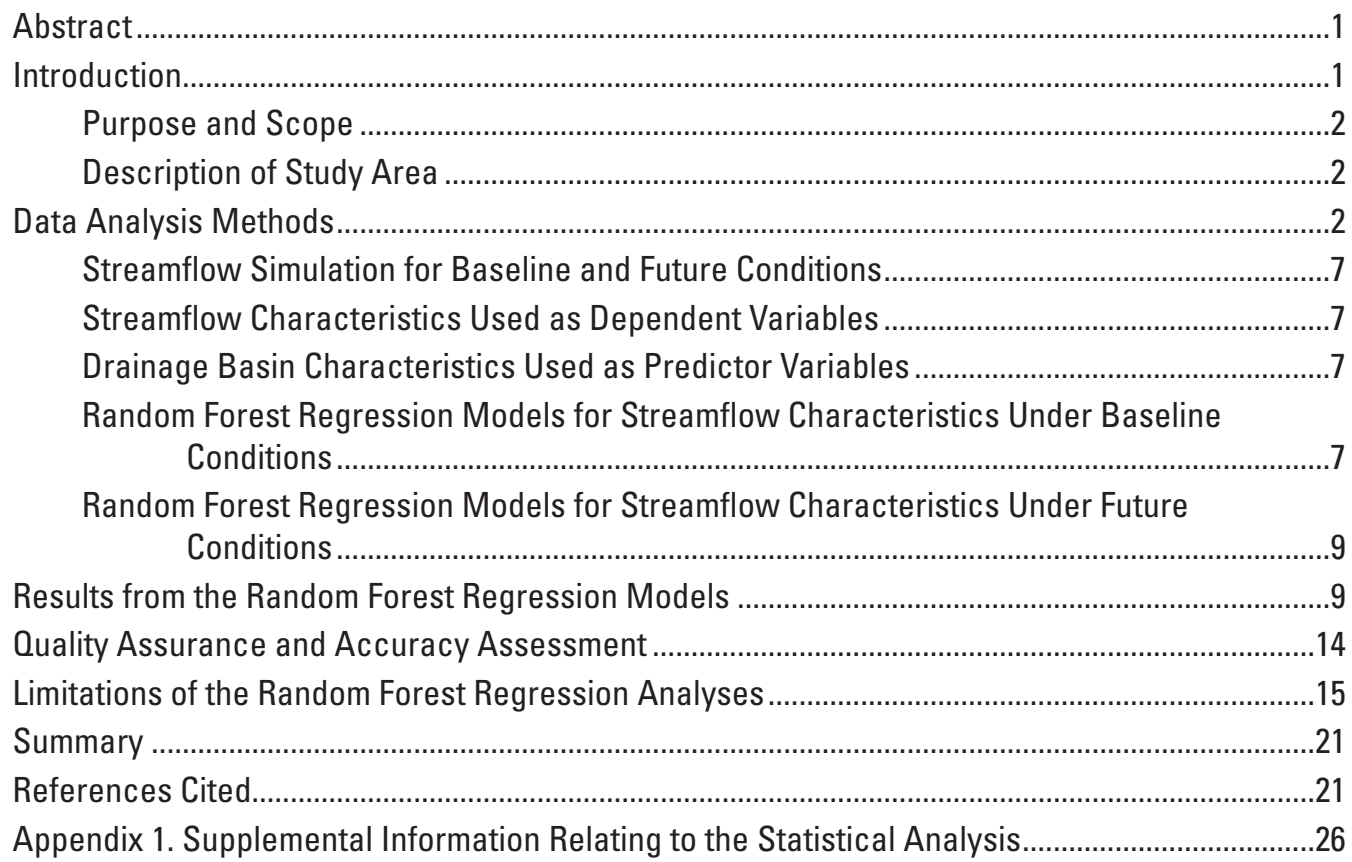

\section{Figures}

1. Map showing drainage basins of fish sampling sites and Precipitation-Runoff Modeling System nodes used in the analysis...................................................................

2. Map showing location of Precipitation-Runoff Modeling System nodes ..........................4

3. Map showing locations of fish sampling sites and Hydrologic Unit Code boundaries

4. Diagram showing steps taken in estimating streamflow characteristics for baseline conditions and future conditions under different potential climate change scenarios

5. Bar graph showing variable importance, shown as the normalized mean reduction in root mean square error, for predictor variables used in this study

6. Map showing locations of fish sampling sites and corresponding PrecipitationRunoff Modeling System nodes used for comparison of predicted and simulated streamflow characteristic values

7. Map showing location of fish sampling sites and corresponding U.S. Geological Survey streamflow-gaging stations used for comparison of predicted and observed streamflow characteristic values 


\section{Tables}

1. Information on streamflow characteristics used as dependent variables .8

2. Information on drainage basin characteristics used as predictor variables..................10

3. Number of predictor variables aggregated and average root mean square error for each random forest prediction model.

4. Mean relative percent difference and coefficient of determination for all predictive models for each comparison pair. .

5. Mean relative percent difference for each prediction model calculated from all comparison pairs.

6. Mean absolute percent error calculated by comparing monthly mean streamflow values predicted at select fish sample sites and monthly mean streamflow values calculated at nearby U.S. Geological Survey streamflow-gaging stations.

\section{Appendix Tables}

1-1. Streamflow characteristics, in cubic feet per second, at Precipitation-Runoff Modeling System nodes calculated from data simulated by Chase and others (2016) for baseline conditions.

1-2. Streamflow characteristics, in cubic feet per second, at Precipitation-Runoff Modeling System nodes calculated from data simulated by Chase and others (2016) for the ECHAM5 2030s scenario

1-3. Streamflow characteristics, in cubic feet per second, at Precipitation-Runoff Modeling System nodes calculated from data simulated by Chase and others (2016) for the ECHAM5 2055s scenario

1-4. Streamflow characteristics, in cubic feet per second, at Precipitation-Runoff Modeling System nodes calculated from data simulated by Chase and others (2016) for the ECHAM5 2080s scenario

1-5. Streamflow characteristics, in cubic feet per second, at Precipitation-Runoff Modeling System nodes calculated from data simulated by Chase and others (2016) for the GENMOM 2030s scenario

1-6. Streamflow characteristics, in cubic feet per second, at Precipitation-Runoff Modeling System nodes calculated from data simulated by Chase and others (2016) for the GENMOM 2055s scenario

1-7. Streamflow characteristics, in cubic feet per second, at Precipitation-Runoff Modeling System nodes calculated from data simulated by Chase and others (2016) for the GENMOM 2080s scenario

1-8. Streamflow characteristics, in cubic feet per second, at Precipitation-Runoff Modeling System nodes calculated from data simulated by Chase and others (2016) for the GFDL 2055s scenario.

1-9. Drainage basin characteristic values for drainage basins associated with

Precipitation-Runoff Modeling System nodes

1-10. Drainage basin characteristic values for drainage basins associated with fish sample sites

1-11. Streamflow characteristics, in cubic feet per second, predicted at fish sampling sites for baseline conditions.

1-12. Streamflow characteristics, in cubic feet per second, predicted at fish sampling sites for the ECHAM5 2030s scenario

1-13. Streamflow characteristics, in cubic feet per second, predicted at fish sampling sites for the ECHAM5 2055s scenario 
1-14. Streamflow characteristics, in cubic feet per second, predicted at fish sampling sites for the ECHAM5 2080s scenario .

1-15. Streamflow characteristics, in cubic feet per second, predicted at fish sampling sites for the GENMOM 2030s scenario

1-16. Streamflow characteristics, in cubic feet per second, predicted at fish sampling sites for the GENMOM 2055s scenario

1-17. Streamflow characteristics, in cubic feet per second, predicted at fish sampling sites for the GENMOM 2080s scenario

1-18. Streamflow characteristics, in cubic feet per second, predicted at fish sampling sites for the GFDL 2055s scenario

\section{Conversion Factors}

U.S. customary units to International System of Units

\begin{tabular}{lll}
\hline \multicolumn{1}{c}{ Multiply } & By & \multicolumn{1}{c}{ To obtain } \\
\hline foot (ft) & Length & \\
mile (mi) & 0.3048 & meter $(\mathrm{m})$ \\
& 1.609 & kilometer $(\mathrm{km})$ \\
\hline square mile $\left(\mathrm{mi}^{2}\right)$ & Area & \\
\hline & 2.590 & square kilometer $\left(\mathrm{km}^{2}\right)$ \\
\hline cubic yard $\left(\mathrm{yd}^{3}\right)$ & Volume & cubic meter $\left(\mathrm{m}^{3}\right)$ \\
\hline & 0.7646 & \\
\hline cubic foot per second $(\mathrm{ft} 3 / \mathrm{s})$ & Flow rate & cubic meter per second $\left(\mathrm{m}^{3} / \mathrm{s}\right)$ \\
inch per month (in $/ \mathrm{month})$ & 0.02832 & meter per month $\left(\mathrm{m} / \mathrm{month}^{3}\right)$ \\
\hline
\end{tabular}

\section{Datum}

Horizontal coordinate information is referenced to the North American Datum of 1983 (NAD 83).

\section{Abbreviations}

$\begin{array}{ll}\text { ECHAM5 } & \text { Max Planck Institute fifth-generation atmospheric general circulation model } \\ \text { GCM } & \text { general circulation model } \\ \text { GENMOM } & \text { coupled atmospheric-ocean climate model } \\ \text { GFDL } & \text { Geophysical Fluid Dynamics Laboratory coupled model 2.0 } \\ \text { PRMS } & \text { Precipitation-Runoff Modeling System } \\ R^{2} & \text { coefficient of determination } \\ \text { RegCM3 } & \text { regional climate model } \\ \text { RF } & \text { random forest } \\ \text { RMSE } & \text { root mean squared error } \\ \text { USGS } & \text { U.S. Geological Survey } \\ \text { WY } & \text { water year }\end{array}$




\section{Acknowledgments}

Special thanks are given to the Plains and Prairie Potholes Landscape Conservation Center and the Bureau of Land Management for their support of this project.

The authors would like to thank Bob Bramblett and Alexander Zale, both of the Montana Cooperative Fisheries Research Unit, Dave Roberts of Montana State University, and Bob Gresswell of the U.S. Geological Survey (retired) for their hard work and valuable input on this project. The authors would also like to thank Skip Vecchia (retired) and Nicholas Paretti of the U.S. Geological Survey for their fantastic reviews and advice on the organization and content of this report. 


\title{
Estimating Current and Future Streamflow Characteristics at Ungaged Sites, Central and Eastern Montana, with Application to Evaluating Effects of Climate Change on Fish Populations
}

\author{
By Roy Sando and Katherine J. Chase
}

\section{Abstract}

A common statistical procedure for estimating streamflow statistics at ungaged locations is to develop a relational model between streamflow and drainage basin characteristics at gaged locations using least squares regression analysis; however, least squares regression methods are parametric and make constraining assumptions about the data distribution. The random forest regression method provides an alternative nonparametric method for estimating streamflow characteristics at ungaged sites and requires that the data meet fewer statistical conditions than least squares regression methods.

Random forest regression analysis was used to develop predictive models for 89 streamflow characteristics using Precipitation-Runoff Modeling System simulated streamflow data and drainage basin characteristics at 179 sites in central and eastern Montana. The predictive models were developed from streamflow data simulated for current (baseline, water years 1982-99) conditions and three future periods (water years 2021-38, 2046-63, and 2071-88) under three different climate-change scenarios. These predictive models were then used to predict streamflow characteristics for baseline conditions and three future periods at 1,707 fish sampling sites in central and eastern Montana. The average root mean square error for all predictive models was about 50 percent. When streamflow predictions at 23 fish sampling sites were compared to nearby locations with simulated data, the mean relative percent difference was about 43 percent. When predictions were compared to streamflow data recorded at 21 U.S. Geological Survey streamflow-gaging stations outside of the calibration basins, the average mean absolute percent error was about 73 percent.

\section{Introduction}

Climate change might have substantial effects on a variety of environmental factors, including hydrology (Barnett and others, 2004; Hay and McCabe, 2010). Potential changes in climate variables (precipitation and temperature) can be simulated into the future with the use of general circulation models (GCMs; Hostetler and others, 2011). When downscaled to the appropriate spatial resolution, GCMs also can be used to provide input to hydrologic models, such as the PrecipitationRunoff Modeling System (PRMS; Leavesly and others, 1983; Chase and others, 2016) to simulate effects of future potential climate change scenarios on drainage basin-scale hydrologic systems. Use of the PRMS, however, requires that the drainage basins being modeled have sufficient records of observed, or gaged, streamflow data for model calibration. Despite this limitation, statistical models developed using the relations among PRMS-simulated streamflow data and drainage basin characteristics can be used to estimate streamflow characteristics at ungaged, or unsimulated, sites.

Relations among streamflow characteristics (for example, annual mean streamflow or monthly 25 th percentile streamflow) and drainage basin characteristics (for example, mean basin elevation or mean annual precipitation) for drainage basins with simulated streamflow data can be used to estimate streamflow characteristics for drainage basins without simulated streamflow data using regression analysis (Wilkowske and others, 2008). Typically, least squares regression methods are used to estimate streamflow characteristics at sites without simulated streamflow data. Despite the usefulness of this modeling technique, least squares regression methods are parametric, and certain assumptions about the data distribution must be met, including multivariate normality, homoscedasticity of residuals, and noncorrelated predictor variables (Helsel and Hirsch, 2002). Additionally, there often are different drainage basin characteristics that influence streamflow characteristics 
in different hydrologic regions (Sando and others, 2016), which necessitates the use of multiple models for optimal predictions in varying hydrologic regions. Finally, least squares methods are not well-suited to make predictions for observations that have predictor variable values outside the range of values used to develop the predictive model.

To avoid the model constraints of least squares regression, random forest (RF) regression analysis (Breiman, 2001) was selected as an alternative nonparametric method for estimating streamflow characteristics. A major advantage of the RF regression analysis in the context of this study is that it does not require that a predictor variable has significant explanatory power in the model, which allows for the inclusion of more predictor variables. The method does this by building an ensemble of regression trees for each predictive model using random subsets of a specified number of predictor variables to build each tree. For each regression tree, the data are recursively partitioned based on the randomly selected subset of predictor variables to maximize between-group variance. Only the most influential predictor variable is used at each partition, which minimizes any effect from correlation among predictor variables. The individual regression trees, or weak learners, are then combined by averaging their predictions into an ensemble, or strong learner. In general, tree regression and classification techniques, including RF regression, also requires less prior knowledge about the underlying regional relations between predictor variables (basin characteristics) and the dependent variable (streamflow characteristics; Prasad and others, 2006). These types of analyses also are better than least squares regression methods at extrapolating predictions for data outside the ranges of the training data (Prasad and others, 2006).

\section{Purpose and Scope}

The purpose of this report is to document the methods and results using RF regression analysis to estimate 89 streamflow characteristics for baseline conditions and two future periods under two potential future climate change scenarios and an additional future period under three potential future climate change scenarios at 1,707 fish sampling sites in central and eastern Montana. The RF regression models were developed using streamflow data simulated with PRMS by Chase and others (2016), in conjunction with drainage basin characteristics at 179 nodes (sites) in central and eastern Montana. A focus of the report is documenting data processing steps and assessing the accuracy of RF regression analysis for estimating streamflow characteristics at ungaged sites. For a more detailed interpretation of the results of the effects of climate change on future streamflow characteristics at PRMS nodes based on simulated data, see Chase and others (2016). This investigation is intended to provide information about hydrologic changes caused by to potential climate change and guide future investigations looking at the effects on fish populations and their distribution throughout eastern and central Montana.

\section{Description of Study Area}

The study area includes drainage basins associated with 179 PRMS nodes (Chase and others, 2016) and 1,707 fish sampling sites (Robert G. Bramblett, Montana State University, unpub. data, 2014) within the Missouri and Yellowstone River Basins (figs. 1 and 2). The study area primarily is in Montana east of the Rocky Mountain front and extends into parts of Alberta, Saskatchewan, North Dakota, and Wyoming.

The sites with simulated streamflow data that were used to develop the RF regression models will be referred to as PRMS nodes. The PRMS nodes and their associated drainage basins are within seven watersheds in eastern and central Montana. These watersheds were selected by Chase and others (2016) for PRMS model development based on minimum requirements that sites had at least 7 years of gaged streamflow data available from representative U.S. Geological Survey (USGS) streamflow-gaging stations within the watershed for calibration and evaluation, and streamflows were not affected by major reservoirs with storage capacities larger than about 16 million cubic yards $\left(\mathrm{yd}^{3}\right)$. The gaged streamflow data used for calibration and evaluation was obtained through the USGS National Water Information System (U.S. Geological Survey, 2014). Three of the watersheds (O'Fallon Creek, Redwater River, and Little Dry Creek) are in eastern Montana, and four of the watersheds (Middle Musselshell River, Judith River, Cottonwood Creek, and Belt Creek) are in central Montana (fig. 2). A detailed description of the PRMS node selection and analysis is in Chase and others (2016).

The 1,707 ungaged fish sampling sites used in the RF regression analysis are locations sampled at various dates ranging from 1999 to 2007 by scientists with the Montana Fish, Wildlife, and Parks, the Montana Cooperative Fishery Research Unit, and Montana State University. The fish sampling sites and associated drainage basins are primarily in central and eastern Montana and extend into Alberta, Saskatchewan, North Dakota, and Wyoming (fig. 3).

\section{Data Analysis Methods}

Estimating streamflow characteristics at fish sampling sites in central and eastern Montana included a series of steps. Those steps are presented in figure 4 and described in this section.

First, mean daily streamflow values were simulated at 188 nodes, or sites, throughout central and eastern Montana using PRMS models by Chase and others (2016) for baseline conditions (associated with water years [WYs] 1982-99) and for three future periods (associated with WYs 2021-38, 2046-63, and 2071-88) under two different potential future climate change scenarios for WYs 2021-38 (2030s) and 2071-88 (2080s) and three different potential future climate scenarios for WYs 2046-63 (2055s). A water year is the 12-month period October 1 through September 30 designated 


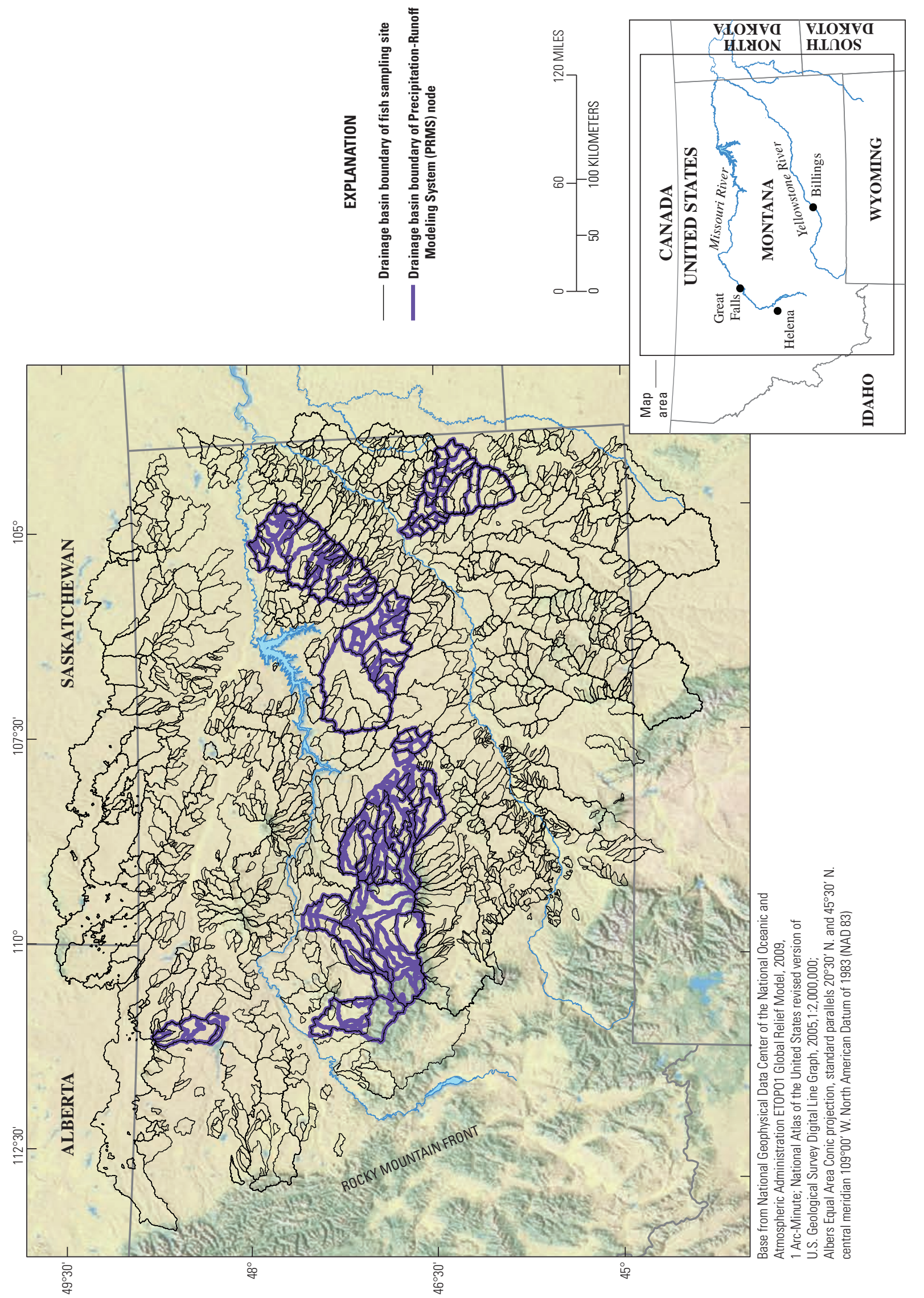

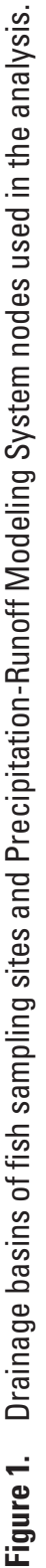




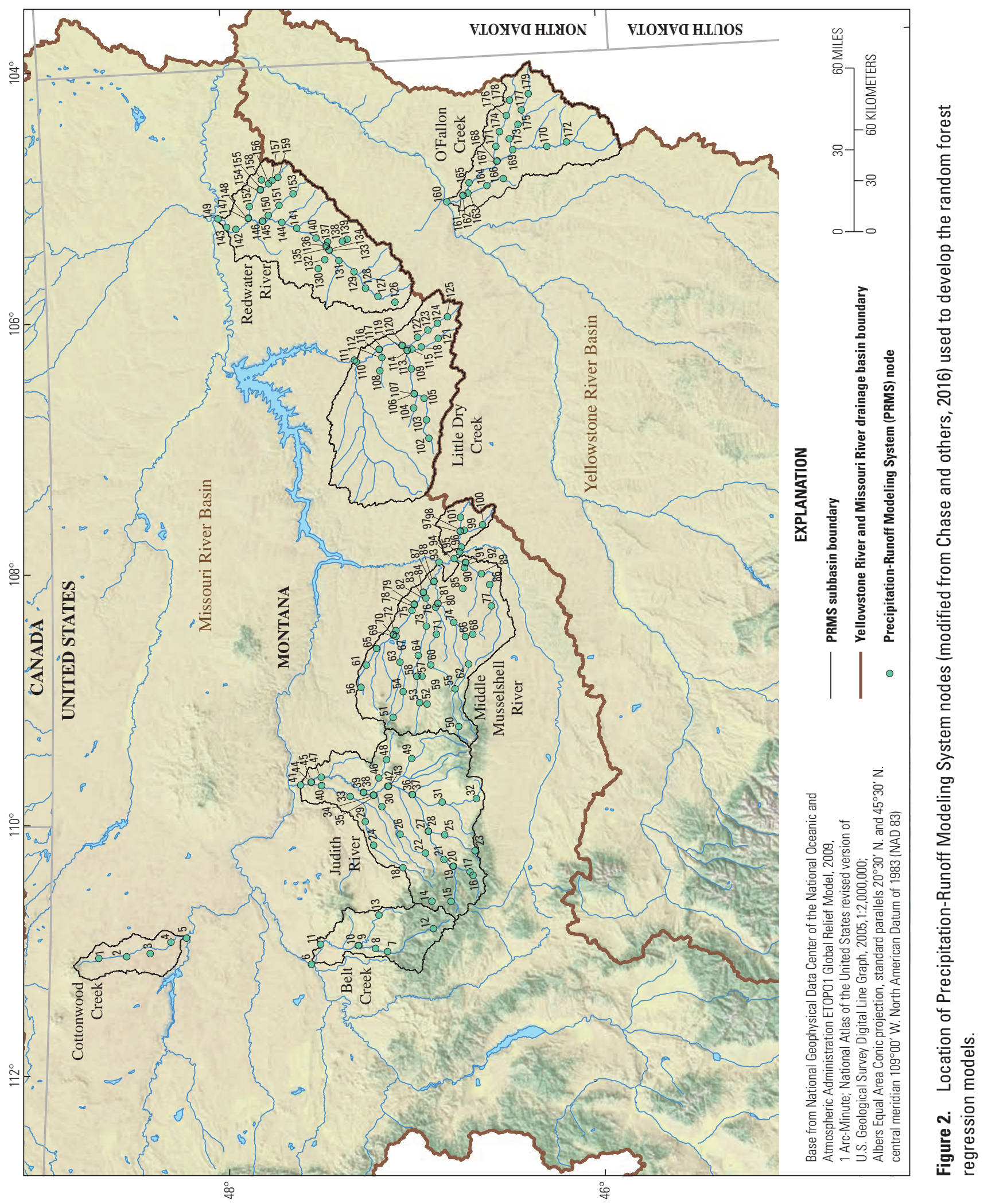




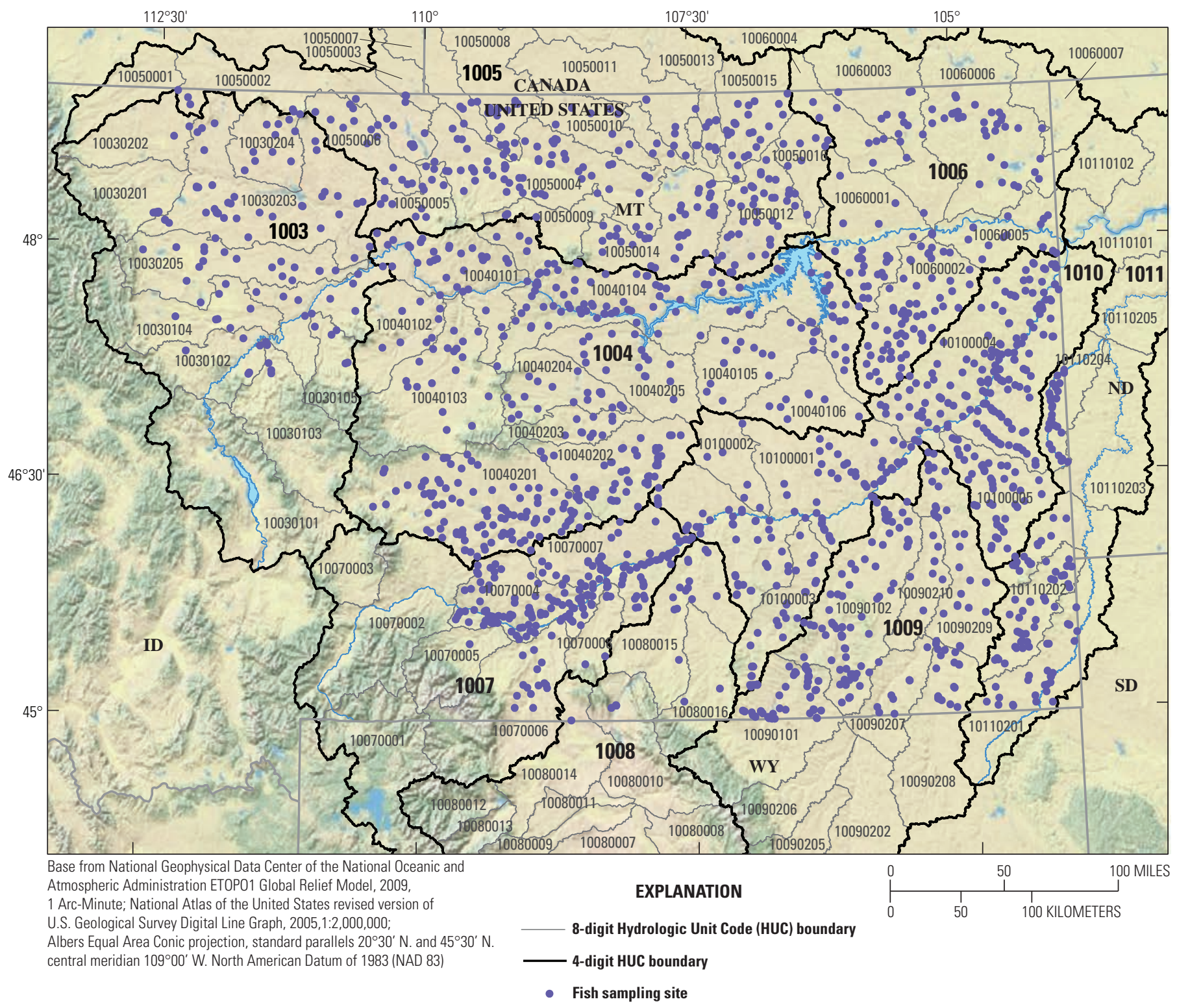

Figure 3. Locations of fish sampling sites and Hydrologic Unit Code boundaries.

by the calendar year in which it ends. A detailed discussion of the PRMS model and climate models used to simulate these data is provided by Chase and others (2016). Of the 188 sites, 9 were downstream from large reservoirs or had large uncertainty and were not included in this investigation, leaving 179 nodes (fig. 2) from which the data was used to develop the RF regression models.

Second, 89 streamflow characteristics (dependent variables) were derived from the streamflow data simulated by Chase and others (2016). The streamflow characteristics were chosen to describe the variability in streamflow that might have an effect on fish populations (B. Bramblett, oral commun., 2015).

Third, drainage basins were delineated for the 179 PRMS nodes (fig. 2) and 1,707 fish sampling sites (fig. 3). These drainage basins were used to calculate 20 drainage basin characteristics (predictor variables) in ArcGIS (Esri, 2014).

Fourth, $89 \mathrm{RF}$ regression models were developed using the 89 streamflow characteristics derived from streamflow data simulated for baseline conditions at the 179 PRMS nodes as dependent variables and the drainage basin characteristics associated with the PRMS nodes as predictor variables. These $\mathrm{RF}$ regression models were then used to predict values for the 89 streamflow characteristics for baseline conditions at the 1,707 fish sampling sites using the drainage basin characteristics associated with the fish sampling sites.

Fifth, 89 RF regression predictive models were developed for each future period and potential future climate change scenario using the 89 streamflow characteristics derived from streamflow data simulated for the respective period and potential future climate change scenario. Because there were 


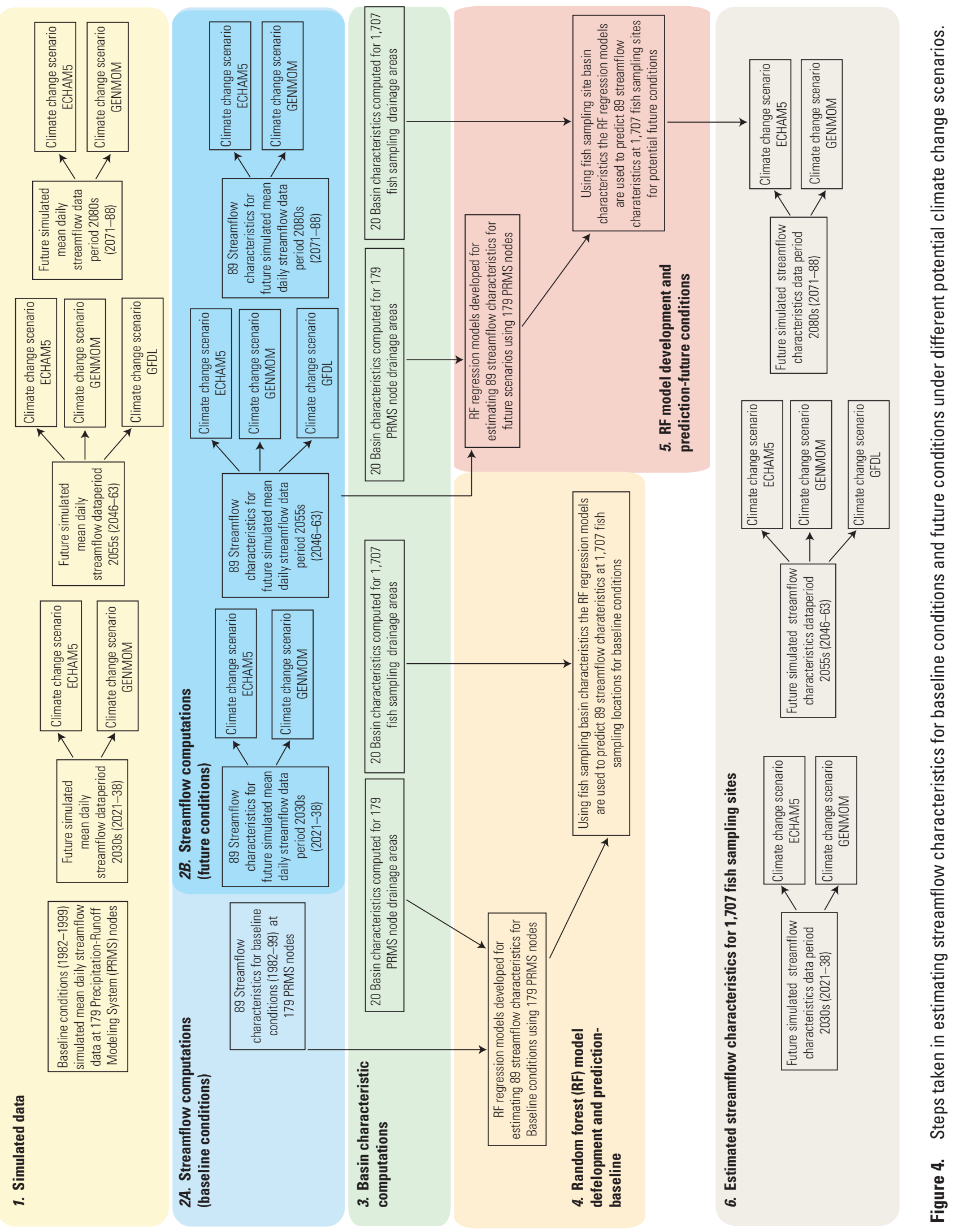


seven different combinations of future periods and potential future climate change scenarios (two for 2030s, three for $2055 \mathrm{~s}$, and two for 2080s), there were a total of 623 regression models developed for estimating potential future streamflow characteristics.

Sixth, the $623 \mathrm{RF}$ regression models were used to estimate streamflow characteristics at the 1,707 fish sampling sites for each future period and potential climate change scenario.

\section{Streamflow Simulation for Baseline and Future Conditions}

The PRMS was used to simulate daily streamflow characteristics at 179 PRMS nodes for a baseline period of WYs 1982-99 and three future periods of WYs 2021-38, 2046-63, and 2071-88 (Chase and others, 2016). Daily streamflow values were averaged to monthly mean streamflow values for analysis in this study because of limitations associated with the PRMS models and with the methods used to estimate the future precipitation and temperature data, which are described by Chase and others (2016).

The PRMS models incorporate climate datasets, which allow for the simulation of future daily streamflow under different potential climate change scenarios. To simulate daily streamflow for future climate change conditions, two steps were required. First, precipitation and temperature values from the Daymet dataset (Thornton and others, 2012) were used as input to the PRMS models for baseline conditions (WYs 1982-99). Second, a third generation of the Regional Climate Model (RegCM3; Hostetler and others, 2011) was used to calculate changes in daily precipitation and temperature from baseline conditions to the three future periods $(2030 \mathrm{~s}, 2055 \mathrm{~s}$, and 2080s). As part of the process of calculating changes in daily precipitation and temperature, the RegCM3 uses the output from a GCM. To simulate a range of potential future climate change scenarios, Chase and others (2016) used three different GCMs. The three GCMs used in the regional climate model were the Geophysical Fluid Dynamics Laboratory coupled model 2.0 (GFDL), the Max Planck Institute fifthgeneration atmospheric general circulation model (ECHAM5), and a coupled atmospheric-ocean climate model (GENMOM; Hostetler and others, 2011). Data from the ECHAM5 and GENMOM GCMs were available for the 2030s, 2055s, and 2080s periods; data from the GFDL GCMs were only available for the $2055 \mathrm{~s}$ period. For a more detailed description of the differences among the three GCMs see Chase and others (2016).

\section{Streamflow Characteristics Used as Dependent Variables}

Streamflow characteristics used as dependent variables were selected based on their considered importance in relation to fish population dynamics in central and eastern Montana
(B. Bramblett, oral commun., 2015). The selected dependent variables provide representation of low- and high-streamflow conditions, and also seasonal and annual variability. The 89 dependent variables (table 1) used to develop the RF regression models were calculated from monthly mean streamflow, in cubic feet per second. Monthly mean streamflow values were obtained by averaging daily streamflow simulated by Chase and others (2016). Values for the 89 dependent variables for current (baseline) conditions and potential future conditions at the 179 PRMS nodes used to develop the RF regression models are presented in tables 1-1 through 1-8 in appendix 1. All streamflow characteristics were log-transformed before analysis to help alleviate nonlinearity in relations among dependent variables and predictor variables.

\section{Drainage Basin Characteristics Used as Predictor Variables}

Drainage basin characteristics used as predictor variables were selected based on hydrologic importance determined from previous research (Parrett and Omang, 1981; Omang, 1992; Parrett and Johnson, 2004; Sando and others, 2016), as well as the availability of data. Drainage basin boundaries for PRMS nodes and fish sampling sites were delineated in ArcMap (Esri, 2014) using the 30-meter National Elevation Dataset (Gesch and others, 2002). A total of 20 drainage basin characteristics (table 2) were calculated using geospatial analysis of digital datasets in ArcMap (Esri, 2014) for all drainage basins associated with PRMS nodes and fish sampling sites. Each drainage basin characteristic was plotted with the dependent variables on scatterplots to determine the need for transformation before statistical analysis. In selecting the transformations, if any, that would improve the relation between drainage basin characteristics and dependent variables, consideration was given to (1) improvement of the coefficient of determination $\left(\mathrm{R}^{2}\right)$ and (2) transformations that were used in a similar analysis completed by Sando and others (2016). Any transformations applied to drainage basin characteristics before analysis are shown in table 2. Drainage basin characteristics for drainage basins associated with each PRMS node are presented in table 1-9 in appendix 1. Drainage basin characteristics for drainage basins associated with each fish sampling site are presented in table 1-10 in appendix 1 .

\section{Random Forest Regression Models for Streamflow Characteristics Under Baseline Conditions}

Regression models were developed using RF regression analysis (Breiman, 2001), as implemented by Liaw and Wiener (2002) in the "randomForest" statistical package built for the R statistical software (R Core Team, 2014). The RF analysis is a nonparametric analysis that creates a specified number of regression trees $(5,000$ for this study) with each tree being 
Table 1. Information on streamflow characteristics used as dependent variables.

$[\mathrm{X}$, month; Y, season]

\begin{tabular}{|c|c|c|c|c|}
\hline $\begin{array}{l}\text { Variable } \\
\text { number }\end{array}$ & $\begin{array}{l}\text { Variable } \\
\text { designation }\end{array}$ & Description & Calculation & $\begin{array}{c}\text { Total } \\
\text { number of } \\
\text { output } \\
\text { values per } \\
\text { site }\end{array}$ \\
\hline \multicolumn{5}{|c|}{ Monthly streamflow characteristics } \\
\hline $1-12$ & MXp25 & $\begin{array}{l}\text { 25th percentile monthly flow (for month } \mathrm{X} ; \mathrm{X}=1 \\
\text { through } 12 \text { ) }\end{array}$ & $\begin{array}{l}\text { Percentile command applied to } 18 \text { baseline } \\
\text { period monthly mean flows for month } \mathrm{x}\end{array}$ & 12 \\
\hline $13-24$ & MXp50 & $\begin{array}{l}\text { 50th percentile (median) monthly flow (for month } X \text {; } \\
\quad X=1 \text { through } 12 \text { ) }\end{array}$ & $\begin{array}{l}\text { Percentile command applied to } 18 \text { baseline } \\
\text { period monthly mean flows for month } \mathrm{x}\end{array}$ & 12 \\
\hline $25-36$ & MXp75 & $\begin{array}{l}\text { 75th percentile monthly flow (for month } \mathrm{X} ; \mathrm{X}=1 \\
\text { through } 12 \text { ) }\end{array}$ & $\begin{array}{l}\text { Percentile command applied to } 18 \text { baseline } \\
\text { period monthly mean flows for month } \mathrm{x}\end{array}$ & 12 \\
\hline $37-48$ & MXmean & Mean monthly flow (for month $\mathrm{X} ; \mathrm{X}=1$ through 12 ) & $\begin{array}{l}\text { Mean of the } 18 \text { baseline period monthly mean } \\
\text { flows for month } x\end{array}$ & 12 \\
\hline $53-56$ & sYminp50 & $\begin{array}{l}\text { Minimum 50th percentile (median) monthly flow in } \\
\text { season } Y(Y=1 \text { through } 4)\end{array}$ & $\begin{array}{l}\text { Minimum of the } 350 \text { th percentile monthly } \\
\text { flows (variable } 2) \text { in season } y(y=1 \text { through } 4)\end{array}$ & 4 \\
\hline $57-60$ & sYmaxp75 & $\begin{array}{l}\text { Maximum 75th percentile monthly flow in season } Y \\
(Y=1 \text { through } 4)\end{array}$ & $\begin{array}{l}\text { Maximum of the } 375 \text { th percentile monthly } \\
\text { flows (variable } 3) \text { in season } y(y=1 \text { through } 4)\end{array}$ & 4 \\
\hline $61-64$ & sYmaxmean & $\begin{array}{l}\text { Maximum mean monthly flow in season } Y(Y=1 \\
\text { through 4) }\end{array}$ & $\begin{array}{l}\text { Maximum of the } 3 \text { mean monthly flows (vari- } \\
\text { able } 4) \text { in season } y(y=1 \text { through } 4)\end{array}$ & 4 \\
\hline 68 & Amaxmean & Maximum mean monthly flow in annual period & $\begin{array}{l}\text { Maximum of the } 12 \text { mean monthly flows (vari- } \\
\text { able 4) in annual period }\end{array}$ & 1 \\
\hline \multicolumn{5}{|c|}{ Seasonal streamflow characteristics } \\
\hline $69-72$ & sYp25 & $\begin{array}{l}\text { 25th percentile seasonal flow in season } Y(Y=1 \\
\text { through 4) }\end{array}$ & $\begin{array}{l}\text { Mean of the } 325 \text { th percentile monthly flows } \\
\text { (variable } 1) \text { in season } y(y=1 \text { through } 4)\end{array}$ & 4 \\
\hline $73-76$ & sYp50 & $\begin{array}{l}\text { 50th percentile (median) seasonal flow in season } Y \\
(Y=1 \text { through } 4)\end{array}$ & $\begin{array}{l}\text { Mean of the } 350 \text { th percentile monthly flows } \\
\text { (variable } 2) \text { in season } \mathrm{y}(\mathrm{y}=1 \text { through } 4)\end{array}$ & 4 \\
\hline $77-80$ & sYp75 & $\begin{array}{l}\text { 75th percentile seasonal flow in season } Y(Y=1 \\
\text { through 4) }\end{array}$ & $\begin{array}{l}\text { Mean of the } 375 \text { th percentile monthly flows } \\
\text { (variable } 3) \text { in season } y(y=1 \text { through } 4)\end{array}$ & 4 \\
\hline $81-84$ & sYmean & Mean seasonal flow in season $Y(Y=1$ through 4$)$ & $\begin{array}{l}\text { Mean of the } 3 \text { mean monthly flows (variable 4) } \\
\text { for season } y(y=1 \text { through } 4)\end{array}$ & 4 \\
\hline
\end{tabular}


Table 1. Information on streamflow characteristics used as dependent variables.-Continued

$[\mathrm{X}$, month; $\mathrm{Y}$, season]

\begin{tabular}{|c|c|c|c|c|}
\hline $\begin{array}{l}\text { Variable } \\
\text { number }\end{array}$ & $\begin{array}{c}\text { Variable } \\
\text { designation }\end{array}$ & Description & Calculation & $\begin{array}{c}\text { Total } \\
\text { number of } \\
\text { output } \\
\text { values per } \\
\text { site }\end{array}$ \\
\hline \multicolumn{5}{|c|}{ Annual streamflow characteristics } \\
\hline 85 & Ap25 & $\begin{array}{l}\text { 25th percentile annual flow (months } Y=1 \text { through } \\
\text { 12) }\end{array}$ & $\begin{array}{l}\text { Mean of the } 12 \text { 25th percentile monthly flows } \\
\text { (variable 1) in annual period }\end{array}$ & 1 \\
\hline 86 & Ap50 & $\begin{array}{l}\text { 50th percentile (median) annual flow (months } Y=1 \\
\text { through 12) }\end{array}$ & $\begin{array}{l}\text { Mean of the } 12 \text { 50th percentile monthly flows } \\
\text { (variable 2) in annual period }\end{array}$ & 1 \\
\hline 87 & Ap75 & $\begin{array}{l}\text { 75th percentile annual flow (months } Y=1 \text { through } \\
\text { 12) }\end{array}$ & $\begin{array}{l}\text { Mean of the } 1275 \text { th percentile monthly flows } \\
\text { (variable } 3 \text { ) in annual period }\end{array}$ & 1 \\
\hline 89 & Arange & $\begin{array}{l}\text { Range of mean monthly flows (months } Y=1 \text { through } \\
\text { 12) }\end{array}$ & $\begin{array}{l}\text { Maximum of the } 12 \text { mean monthly flows minus } \\
\text { minimum of the } 12 \text { mean monthly flows in } \\
\text { annual period }\end{array}$ & 1 \\
\hline
\end{tabular}

built using a specified number of randomly chosen predictor variables (process referred to as aggregating) and two-thirds of the observations, also chosen randomly (process referred to as bootstrapping). All the predictions from each regression tree, or weak learner, are then combined and averaged for each observation to produce a strong learner that is more robust than if the predictions were made using only one regression tree. By randomly selecting subsets of predictor variables and observations for each regression tree and subsequently recombining the data by averaging the results of all the trees, the RF method avoids the assumptions associated with parametric regression methods, such as least squares methods. Optimal numbers of predictor variables aggregated (randomly selected as a subset) for each regression model were determined using the TuneRF function (Liaw and Wiener, 2002) and are shown in table 3. The TuneRF function develops RF regression models under all possible parameter settings and allows the user to compare the average root mean square error (RMSE) of all models.

$\mathrm{RF}$ regression analysis allows for the calculation of RMSE by making predictions for one-third of observations that are excluded from each individual regression tree, comparing those predictions to the actual value, calculating the RMSE for each tree, and averaging those RMSEs for all trees in the RF regression model. The final average RMSE for each RF regression model was converted from log units to percent using the conversion method published by Tasker (1978). Once the model is trained on simulated data, predictions can be made at new sites using predictor variable data associated with the new sites.

\section{Random Forest Regression Models for Streamflow Characteristics Under Future Conditions}

RF regression models were developed for each future period and climate change scenario combination using the same parameters as the RF regression models developed for baseline conditions. All the RF regression model parameters were left the same to ensure consistency in the errors introduced by the models. The future RF regression models were trained using streamflow variables derived from PRMS models for each respective future period and climate change scenario combination. Predictions of the 89 streamflow characteristics were made at each of the 1,707 fish sampling sites for each future period and climate change scenario combination.

\section{Results from the Random Forest Regression Models}

A total of $712 \mathrm{RF}$ regression models were developed using 89 dependent variables for baseline conditions and 7 future time period and climate change scenario combinations. Predicted values for streamflow characteristics at 1,707 fish sampling sites are presented for baseline conditions, and future periods with climate scenarios: ECHAM5 2030s, ECHAM5 2055s, ECHAM5 2080s, GENMOM 2030s, GENMOM 2055s, GENMOM 2080s, and GFDL 2055s in tables $1-11$ through $1-18$, respectively. 
Table 2. Information on drainage basin characteristics used as predictor variables.

\begin{tabular}{|c|c|c|c|}
\hline Variable name & $\begin{array}{c}\text { Variable } \\
\text { designation }\end{array}$ & Description & Transformation used \\
\hline Maximum basin elevation & ELEVMAX & Maximum elevation of drainage basin, in feet ${ }^{1}$ & Log base $10(X / 1,000)$ \\
\hline Minimum basin elevation & MINBELEV & Minimum drainage basin elevation, in feet ${ }^{1}$ & Log base $10(X / 1,000)$ \\
\hline Contributing drainage area & CONTDA & $\begin{array}{l}\text { Area that contributes flow to a point on a stream, in square miles, } \\
\text { delineated using } 30 \text {-meter elevation } \text { data }^{1}\end{array}$ & Log base $10(X)$ \\
\hline Mean basin elevation & ELEV & Mean elevation of drainage basin, in feet ${ }^{1}$ & Log base $10(X / 1,000)$ \\
\hline Percent above 6,000 feet & EL6000 & Percent of drainage basin above 6,000 feet elevation ${ }^{1}$ & Log base $10(X+1)$ \\
\hline Percent above 6,500 feet & EL6500 & Percent of drainage basin above 6,500 feet elevation ${ }^{1}$ & Log base $10(X+1)$ \\
\hline $\begin{array}{l}\text { Percent of basin with slope } \\
\text { greater than } 30 \text { percent }\end{array}$ & SLOP30_30M & $\begin{array}{l}\text { Percent of drainage basin with slopes greater than or equal to } 30 \\
\text { percent, computed from the } 30 \text {-meter elevation data }{ }^{1}\end{array}$ & Log base $10(X+1)$ \\
\hline $\begin{array}{l}\text { Percent of basin with north- } \\
\text { facing slope greater than } \\
30 \text { percent }\end{array}$ & NFSL30_30M & $\begin{array}{l}\text { Percent of drainage basin with north-facing slopes greater than or } \\
\text { equal to } 30 \text { percent computed from } 30 \text {-meter elevations data }{ }^{1}\end{array}$ & Log base $10(X+1)$ \\
\hline $\begin{array}{l}\text { Percent of basin with slope } \\
\text { greater than } 50 \text { percent }\end{array}$ & SLOP50_30M & $\begin{array}{l}\text { Percent of drainage basin with slopes greater than or equal to } 50 \\
\text { percent computed from the } 30 \text {-meter elevation data }{ }^{1}\end{array}$ & Log base $10(X+1)$ \\
\hline Compactness ratio & COMPRAT & $\begin{array}{l}\text { A measure of basin shape related to basin perimeter and drainage } \\
\text { area. Calculated as PERIMMI } /\left(2 *(3.14159 * \text { CONTDA })^{\wedge} 0.5\right)\end{array}$ & Log base $10(X)$ \\
\hline $\begin{array}{l}\text { Mean spring evapotranspira- } \\
\text { tion }\end{array}$ & ET0306MOD & $\begin{array}{l}\text { Mean (2000-12) spring (March-June) evapotranspiration, in inches } \\
\text { per month }{ }^{4}\end{array}$ & Untransformed \\
\hline $\begin{array}{l}\text { Mean summer evapotrasn- } \\
\text { piration }\end{array}$ & ET0710MOD & $\begin{array}{l}\text { Mean (2000-12) summer (July-October) evapotranspiration, in } \\
\text { inches per month }{ }^{4}\end{array}$ & Untransformed \\
\hline
\end{tabular}

${ }^{1}$ Elevation and related variables determined or calculated from the National Elevation Dataset (NED; Gesch and others, 2002).

${ }^{2}$ Land cover variables determined from the 2001 National Land Cover Dataset (NLCD; Homer and others, 2007) and Land Cover, circa 2000-vector (LCC2000; Natural Resources Canada, 2009).

${ }^{3}$ Percent of drainage basin in lakes, ponds, or reservoirs determined from the National Hydrography Dataset (NHD) version 2 high resolution dataset (Horizon Systems Corporation, 2013).

${ }^{4}$ Evapotranspiration determined from the Moderate Resolution Imaging Spectroradiometer (MODIS) global evapotranspiration product (MOD16) data (Mu and others, 2007). 
Model performance was assessed using the average RMSE, which was generated for each model based on internal cross validation of the RF regression model. The average RMSEs for all RF regression models are shown in table 3 . The minimum average RMSE for all predictive models was about 33 percent (M4p50 for ECHAM5 2080s). The maximum average RMSE for all predictive models was about 80 percent (S1maxp75 for ECHAM5 2030s). The mean average RMSE for all predictive models was about 50 percent. For comparison, average standard errors of prediction associated with regional generalized least squares regression equations developed for estimating flood frequency values in three hydrologic regions in eastern Montana ranged from about 51 percent to about 208 percent (Sando and others, 2016). Although these error metrics are not directly comparable because of differences in dependent variables, independent variables, and model error calculations, they are both relative measures of uncertainty around model performance and RF on average has lower RMSEs.

An advantage of aggregating the predictor variables in the RF regression process is that a measure of variable importance can be determined. This is done by comparing the mean RMSE of the regression trees in the RF model in which the particular variable was included to the mean RMSE of the regression trees in the RF model in which the particular variable was excluded. The mean difference of these two values is then normalized by the standard deviation of the differences. Variable importances, shown as the normalized mean reduction in RMSE, for predictor variables used in this study are shown in figure 5 .

It is important to consider that using changes in precipitation and temperature simulated with the use of GCMs to estimate the potential effect of climate change scenarios on hydrology places emphasis on the change in streamflow characteristics values from the baseline period to future periods. As such, higher errors in the absolute streamflow characteristics values are potentially more acceptable in this study than other studies aimed at estimating streamflow characteristics. As long as the source of uncertainty remains consistent throughout the models, the change in streamflow characteristics values can be considered reliable.

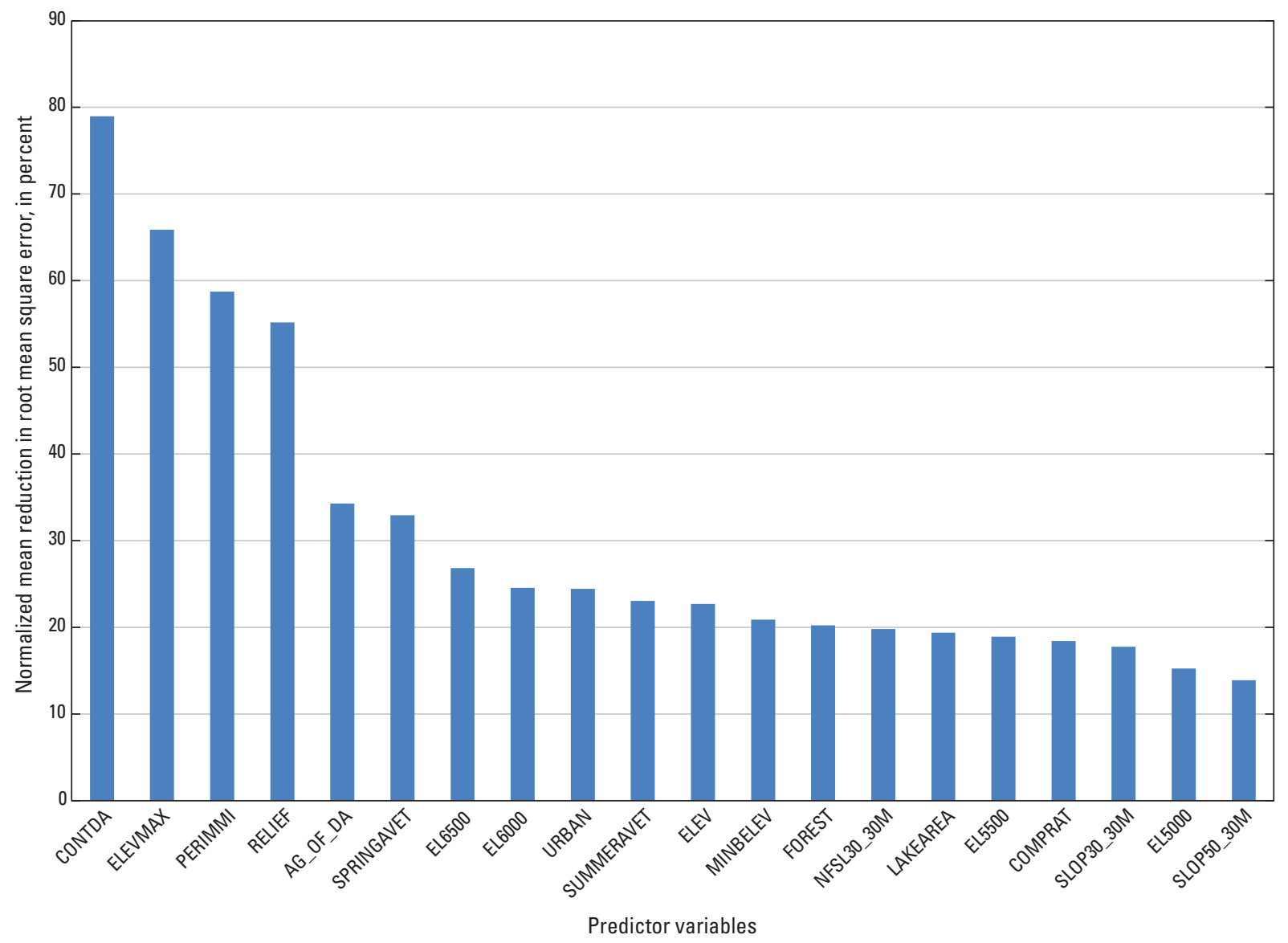

Figure 5. Variable importance, shown as the normalized mean reduction in root mean square error, for predictor variables used in this study. 
Table 3. Number of predictor variables aggregated and average root mean square error for each random forest prediction model.

\begin{tabular}{|c|c|c|c|c|c|c|c|c|c|}
\hline \multirow{2}{*}{$\begin{array}{c}\text { Dependent } \\
\text { variable }\end{array}$} & \multirow{2}{*}{$\begin{array}{c}\text { Number of } \\
\text { predictor } \\
\text { variables } \\
\text { aggregated' }^{1}\end{array}$} & \multicolumn{8}{|c|}{ Average root mean square error, in percent } \\
\hline & & $\begin{array}{l}\text { Baseline } \\
\text { conditions }\end{array}$ & $\begin{array}{l}\text { ECHAM5 } \\
2030 \mathrm{~s}\end{array}$ & $\begin{array}{l}\text { ECHAM5 } \\
\text { 2055s }\end{array}$ & $\begin{array}{l}\text { ECHAM5 } \\
2080 \mathrm{~s}\end{array}$ & $\begin{array}{l}\text { GENMOM } \\
2030 \mathrm{~s}\end{array}$ & $\begin{array}{l}\text { GENMOM } \\
2055 \mathrm{~s}\end{array}$ & $\begin{array}{l}\text { GENMOM } \\
\text { 2080s }\end{array}$ & GFDL 2055s \\
\hline M1p25 & 7 & 54.99 & 54.83 & 49.46 & 48.29 & 55.51 & 54.78 & 49.19 & 48.47 \\
\hline M2p25 & 14 & 56.68 & 56.47 & 39.05 & 38.45 & 55.74 & 56.27 & 50.47 & 49.84 \\
\hline M3p25 & 14 & 58.90 & 58.98 & 42.64 & 35.50 & 57.62 & 57.92 & 53.80 & 51.30 \\
\hline M4p25 & 14 & 62.42 & 56.17 & 39.21 & 37.15 & 62.62 & 59.15 & 51.69 & 51.77 \\
\hline M5p25 & 14 & 46.74 & 44.12 & 41.33 & 35.74 & 46.27 & 47.71 & 44.71 & 41.65 \\
\hline M6p25 & 14 & 45.91 & 44.22 & 46.51 & 44.85 & 45.96 & 44.44 & 40.14 & 39.24 \\
\hline M7p25 & 7 & 44.61 & 44.03 & 60.36 & 50.89 & 43.91 & 44.20 & 39.84 & 39.59 \\
\hline M8p25 & 7 & 47.30 & 46.45 & 44.00 & 36.41 & 47.33 & 47.32 & 43.97 & 43.22 \\
\hline M9p25 & 7 & 48.90 & 45.97 & 56.88 & 51.52 & 49.19 & 48.10 & 43.51 & 41.35 \\
\hline M10p25 & 14 & 53.26 & 49.39 & 49.48 & 42.21 & 53.17 & 51.07 & 46.34 & 43.66 \\
\hline M11p25 & 14 & 53.99 & 51.83 & 54.09 & 53.25 & 53.16 & 51.69 & 46.04 & 45.67 \\
\hline M12p25 & 7 & 53.54 & 52.33 & 49.24 & 43.55 & 53.15 & 52.19 & 46.74 & 45.64 \\
\hline M1p50 & 7 & 60.32 & 60.16 & 46.73 & 46.29 & 59.99 & 58.38 & 55.09 & 51.77 \\
\hline M2p50 & 14 & 62.10 & 61.63 & 37.68 & 35.82 & 60.07 & 60.80 & 55.73 & 53.23 \\
\hline M3p50 & 14 & 62.32 & 60.88 & 39.74 & 34.47 & 59.61 & 62.38 & 58.02 & 56.00 \\
\hline M4p50 & 14 & 64.09 & 53.90 & 35.47 & 33.39 & 59.10 & 56.65 & 52.92 & 52.17 \\
\hline M5p50 & 14 & 51.30 & 49.03 & 41.08 & 37.50 & 51.85 & 51.88 & 47.91 & 45.61 \\
\hline M6p50 & 14 & 51.03 & 49.09 & 42.16 & 40.95 & 49.05 & 47.95 & 44.17 & 43.70 \\
\hline M7p50 & 7 & 46.07 & 44.68 & 55.20 & 47.94 & 45.17 & 44.35 & 42.39 & 40.78 \\
\hline M8p50 & 14 & 47.69 & 44.94 & 40.86 & 35.97 & 47.33 & 45.24 & 42.07 & 43.43 \\
\hline M9p50 & 7 & 51.82 & 49.70 & 59.21 & 54.70 & 50.96 & 49.66 & 46.53 & 43.36 \\
\hline M10p50 & 14 & 52.29 & 51.19 & 45.44 & 40.45 & 53.62 & 50.56 & 45.52 & 43.75 \\
\hline M11p50 & 7 & 57.65 & 55.02 & 60.58 & 53.57 & 58.51 & 55.59 & 50.47 & 47.45 \\
\hline M12p50 & 7 & 59.29 & 57.67 & 46.37 & 40.94 & 58.90 & 57.35 & 51.92 & 48.50 \\
\hline M1p75 & 7 & 64.16 & 63.08 & 48.10 & 42.38 & 62.04 & 62.43 & 59.96 & 55.37 \\
\hline M2p75 & 7 & 72.49 & 76.11 & 41.43 & 40.41 & 73.19 & 67.46 & 62.09 & 60.72 \\
\hline M3p75 & 14 & 72.11 & 76.52 & 40.33 & 37.50 & 71.67 & 74.04 & 65.24 & 62.57 \\
\hline M4p75 & 7 & 61.40 & 58.41 & 35.87 & 34.68 & 59.41 & 59.08 & 56.71 & 52.90 \\
\hline M5p75 & 14 & 52.25 & 52.39 & 40.24 & 39.10 & 52.58 & 56.23 & 52.15 & 50.42 \\
\hline M6p75 & 7 & 54.58 & 52.14 & 47.27 & 44.08 & 52.99 & 53.02 & 48.54 & 48.17 \\
\hline M7p75 & 14 & 48.57 & 46.97 & 53.13 & 45.61 & 45.27 & 46.02 & 43.01 & 40.49 \\
\hline M8p75 & 7 & 45.39 & 45.81 & 43.53 & 43.53 & 44.07 & 44.14 & 41.13 & 42.65 \\
\hline M9p75 & 7 & 50.27 & 46.73 & 50.33 & 49.28 & 50.55 & 47.67 & 44.03 & 42.67 \\
\hline M10p75 & 14 & 52.74 & 51.20 & 48.49 & 45.45 & 53.75 & 51.79 & 47.16 & 45.87 \\
\hline M11p75 & 7 & 60.00 & 57.41 & 52.42 & 51.79 & 59.85 & 58.16 & 51.56 & 48.62 \\
\hline M12p75 & 14 & 63.42 & 61.22 & 42.84 & 39.44 & 62.20 & 60.93 & 53.41 & 50.26 \\
\hline M1mean & 4 & 72.93 & 76.35 & 50.53 & 48.01 & 64.39 & 72.06 & 61.26 & 58.48 \\
\hline M2mean & 7 & 71.75 & 70.36 & 39.55 & 37.27 & 70.43 & 67.64 & 64.68 & 61.59 \\
\hline M3mean & 7 & 67.73 & 73.35 & 45.67 & 46.52 & 66.71 & 75.77 & 62.85 & 59.88 \\
\hline M4mean & 14 & 57.69 & 55.08 & 40.51 & 39.62 & 58.01 & 56.23 & 50.21 & 49.59 \\
\hline M5mean & 7 & 54.01 & 52.88 & 39.41 & 37.29 & 50.99 & 53.47 & 49.66 & 48.79 \\
\hline M6mean & 14 & 54.43 & 54.51 & 45.92 & 42.77 & 52.48 & 51.96 & 48.30 & 50.20 \\
\hline
\end{tabular}


Table 3. Number of predictor variables aggregated and average root mean square error for each random forest prediction model.Continued

\begin{tabular}{|c|c|c|c|c|c|c|c|c|c|}
\hline \multirow{2}{*}{$\begin{array}{c}\text { Dependent } \\
\text { variable }\end{array}$} & \multirow{2}{*}{$\begin{array}{l}\text { Number of } \\
\text { predictor } \\
\text { variables } \\
\text { aggregated }\end{array}$} & \multicolumn{8}{|c|}{ Average root mean square error, in percent } \\
\hline & & $\begin{array}{l}\text { Baseline } \\
\text { conditions }\end{array}$ & $\begin{array}{l}\text { ECHAM5 } \\
2030 \mathrm{~s}\end{array}$ & $\begin{array}{c}\text { ECHAM5 } \\
2055 \mathrm{~s}\end{array}$ & $\begin{array}{c}\text { ECHAM5 } \\
2080 \mathrm{~s}\end{array}$ & $\begin{array}{l}\text { GENMOM } \\
2030 \mathrm{~s}\end{array}$ & $\begin{array}{c}\text { GENMOM } \\
2055 \mathrm{~s}\end{array}$ & $\begin{array}{l}\text { GENMOM } \\
2080 \mathrm{~s}\end{array}$ & GFDL 2055s \\
\hline M8mean & 7 & 44.92 & 46.23 & 45.43 & 46.12 & 42.57 & 41.86 & 38.31 & 38.67 \\
\hline M9mean & 7 & 45.40 & 48.18 & 49.57 & 44.01 & 46.53 & 46.96 & 42.72 & 41.62 \\
\hline M11mean & 14 & 54.16 & 50.93 & 56.35 & 52.81 & 53.57 & 50.99 & 46.41 & 46.98 \\
\hline M12mean & 7 & 62.53 & 60.09 & 45.97 & 43.19 & 61.49 & 62.04 & 54.32 & 52.47 \\
\hline S1minp25 & 14 & 56.94 & 55.65 & 42.73 & 36.72 & 57.45 & 55.93 & 50.26 & 50.08 \\
\hline S2minp25 & 14 & 58.64 & 52.04 & 41.56 & 36.85 & 57.33 & 53.40 & 45.52 & 46.83 \\
\hline S3minp25 & 14 & 49.23 & 47.00 & 53.04 & 44.86 & 49.20 & 47.86 & 44.02 & 42.83 \\
\hline S2minp50 & 14 & 59.00 & 52.84 & 42.31 & 38.10 & 53.10 & 49.67 & 46.79 & 48.27 \\
\hline S3minp50 & 7 & 48.62 & 48.48 & 54.15 & 45.90 & 48.74 & 46.73 & 43.42 & 43.14 \\
\hline S4minp50 & 7 & 59.02 & 58.06 & 54.19 & 48.47 & 58.89 & 58.39 & 51.12 & 48.75 \\
\hline S1maxp75 & 14 & 72.53 & 79.67 & 48.03 & 44.75 & 72.21 & 74.99 & 65.75 & 62.18 \\
\hline S2maxp75 & 14 & 54.48 & 52.82 & 45.99 & 43.60 & 54.12 & 56.55 & 52.68 & 49.66 \\
\hline S3maxp75 & 7 & 47.78 & 46.65 & 43.77 & 42.33 & 45.13 & 45.83 & 42.70 & 40.34 \\
\hline S4maxp75 & 14 & 52.16 & 50.85 & 49.53 & 48.12 & 53.28 & 51.68 & 46.32 & 45.60 \\
\hline S1maxmean & 7 & 71.84 & 75.57 & 52.00 & 54.91 & 69.90 & 70.24 & 66.73 & 63.48 \\
\hline S2maxmean & 7 & 55.66 & 54.86 & 47.68 & 45.58 & 53.22 & 54.67 & 49.89 & 48.41 \\
\hline S1p25 & 14 & 56.34 & 55.38 & 42.37 & 41.27 & 56.85 & 55.98 & 51.20 & 49.38 \\
\hline S2p25 & 14 & 46.71 & 44.65 & 40.89 & 38.60 & 46.80 & 45.66 & 42.34 & 40.52 \\
\hline S3p25 & 7 & 43.47 & 42.11 & 51.56 & 43.98 & 43.90 & 43.62 & 39.12 & 38.53 \\
\hline S4p25 & 4 & 53.18 & 50.47 & 49.96 & 45.33 & 52.66 & 50.99 & 45.37 & 44.15 \\
\hline S1p50 & 14 & 59.79 & 60.05 & 40.56 & 38.77 & 59.48 & 59.43 & 55.85 & 52.75 \\
\hline S2p50 & 7 & 51.69 & 49.19 & 38.56 & 36.08 & 50.98 & 50.77 & 46.84 & 44.36 \\
\hline S3p50 & 14 & 44.71 & 44.30 & 47.49 & 42.39 & 44.88 & 42.72 & 40.93 & 39.91 \\
\hline S4p50 & 7 & 58.27 & 55.93 & 51.22 & 46.02 & 58.17 & 56.17 & 50.48 & 47.62 \\
\hline S1p75 & 7 & 69.40 & 71.72 & 44.24 & 41.73 & 70.41 & 69.20 & 62.67 & 60.44 \\
\hline S2p75 & 14 & 53.57 & 52.59 & 39.49 & 36.92 & 53.02 & 54.69 & 51.19 & 48.15 \\
\hline S3p75 & 7 & 45.13 & 44.88 & 42.64 & 39.26 & 43.62 & 43.12 & 39.27 & 38.18 \\
\hline S4p75 & 7 & 57.50 & 55.03 & 46.14 & 44.06 & 57.80 & 56.46 & 50.45 & 47.79 \\
\hline S1mean & 14 & 69.77 & 72.56 & 44.90 & 42.40 & 67.35 & 70.51 & 60.26 & 60.54 \\
\hline S2mean & 14 & 53.53 & 52.43 & 41.78 & 39.02 & 50.88 & 51.92 & 47.78 & 47.08 \\
\hline S3mean & 7 & 46.90 & 47.87 & 46.06 & 42.39 & 43.77 & 43.15 & 40.23 & 40.65 \\
\hline
\end{tabular}


Table 3. Number of predictor variables aggregated and average root mean square error for each random forest prediction model.Continued

\begin{tabular}{|c|c|c|c|c|c|c|c|c|c|}
\hline \multirow{2}{*}{$\begin{array}{c}\text { Dependent } \\
\text { variable }\end{array}$} & \multirow{2}{*}{$\begin{array}{l}\text { Number of } \\
\text { predictor } \\
\text { variables } \\
\text { aggregated' }\end{array}$} & \multicolumn{8}{|c|}{ Average root mean square error, in percent } \\
\hline & & $\begin{array}{l}\text { Baseline } \\
\text { conditions }\end{array}$ & $\begin{array}{c}\text { ECHAM5 } \\
\text { 2030s }\end{array}$ & $\begin{array}{l}\text { ECHAM5 } \\
\text { 2055s }\end{array}$ & $\begin{array}{l}\text { ECHAM5 } \\
\text { 2080s }\end{array}$ & $\begin{array}{l}\text { GENMOM } \\
\text { 2030s }\end{array}$ & $\begin{array}{l}\text { GENMOM } \\
\text { 2055s }\end{array}$ & $\begin{array}{l}\text { GENMOM } \\
\text { 2080s }\end{array}$ & GFDL 2055s \\
\hline S4mean & 14 & 49.75 & 47.35 & 47.45 & 44.24 & 49.84 & 48.56 & 44.38 & 44.03 \\
\hline Ap25 & 7 & 44.13 & 42.33 & 47.21 & 42.88 & 44.00 & 43.17 & 39.23 & 38.50 \\
\hline Ap50 & 7 & 46.53 & 45.31 & 43.98 & 40.23 & 45.50 & 45.28 & 41.82 & 40.45 \\
\hline Ap75 & 14 & 49.25 & 47.95 & 41.34 & 39.03 & 48.95 & 49.53 & 45.35 & 42.91 \\
\hline Amean & 14 & 45.38 & 47.63 & 42.53 & 40.16 & 43.06 & 46.51 & 43.93 & 40.26 \\
\hline Arange & 7 & 54.97 & 52.26 & 51.72 & 51.26 & 52.80 & 54.10 & 51.52 & 48.90 \\
\hline
\end{tabular}

${ }^{1}$ The term "aggregated" refers to the number of predictor variables randomly selected to build each individual regression tree with. For further explanation, see Brieman (2001).

\section{Quality Assurance and Accuracy Assessment}

Analyses were completed to investigate whether spatial autocorrelation affected the RF regression model results. The PRMS nodes were screened for spatial autocorrelation between sites before building the RF regression models. If more than one node was along the same stream channel, the most upstream node was initially retained. Downstream nodes were evaluated in sequence and were excluded if they did not have at least a 100-percent increase in drainage area (in relation to the next upstream included node). If there were multiple nodes on the same channel and none of them had at least a 100-percent increase in drainage area in relation to the most upstream node, then only the most downstream node was retained. This approach ensured that the streamflow characteristics of the entire stream were captured in the training data, but potential effects of spatial autocorrelation were reduced.

After the data were screened, streamflow data from 118 PRMS nodes were used to train the RF regression models. When the results from the RF regression models developed using the screened baseline conditions data were compared to the results from the RF regression models developed using the unscreened baseline conditions data, there was little difference ( 2 to 5 percent increase in average RMSE). Additionally, the mean relative percent difference of predicted streamflow values at all fish sampling sites from $R F$ regression models developed using screened and unscreened data was about 11 percent; thus, it was determined that the bootstrapping procedure in the RF regression analysis sufficiently accounts for the spatial autocorrelation that is inherent in hydrologic data, and all PRMS nodes were included in building the final RF regression models.

To determine whether or not the RF regression models were estimating reasonable streamflow characteristic values at fish sampling sites in relation to PRMS model outputs, 23 fish sampling sites that were within close proximity and on the same stream as a PRMS node were selected to compare predicted streamflow characteristics values to the original PRMS data. The locations of these fish sampling sites and their corresponding PRMS nodes are shown in figure 6 . The mean relative percent difference and $\mathrm{R}^{2}$ for each comparison pair for each predictive model are provided in table 4 . The mean relative percent difference associated with each dependent variable for predictions based on baseline conditions and each future period and climate change scenario is provided in table 5. The mean relative percent difference was about 43 percent at the 23 comparison sites. The mean relative percent differences were calculated by dividing the difference of two corresponding values by their average.

Although it is to be expected that the models are able to accurately estimate streamflow characteristics near the PRMS nodes, a source of potential uncertainty in the analysis is the assumption that it is feasible to extrapolate PRMS models far outside of the basins used to calibrate the models. The cause of this spatial extrapolation of modeled data is the lack of streamflow-gaging stations distributed throughout the study area available for calibrating the PRMS models (Chase and others, 2016); thus, adequate quantification of this uncertainty is not possible because of the lack of comparable observed data from USGS streamflow-gaging stations in operation in the study area during the baseline period. There are, however, USGS streamflow-gaging stations far outside of the basins used to calibrate the PRMS models that have streamflow records with varying periods of record. Despite the unavailability of directly comparable streamflow data from USGS streamflowgaging stations far outside the basins used to calibrate the PRMS models, a rough measure of the uncertainty introduced from the spatial extrapolation potentially is estimated by comparing monthly mean streamflow predicted at 21 fish sampling sites in close proximity and on the same stream as a USGS streamflow-gaging station to the corresponding monthly mean streamflow values calculated for the nearby streamflow-gaging station (table 6; fig. 7). The mean monthly streamflow characteristics at streamflow-gaging stations that were selected for comparison were obtained from values published by McCarthy (2016). Uncertainty between streamflow characteristics 


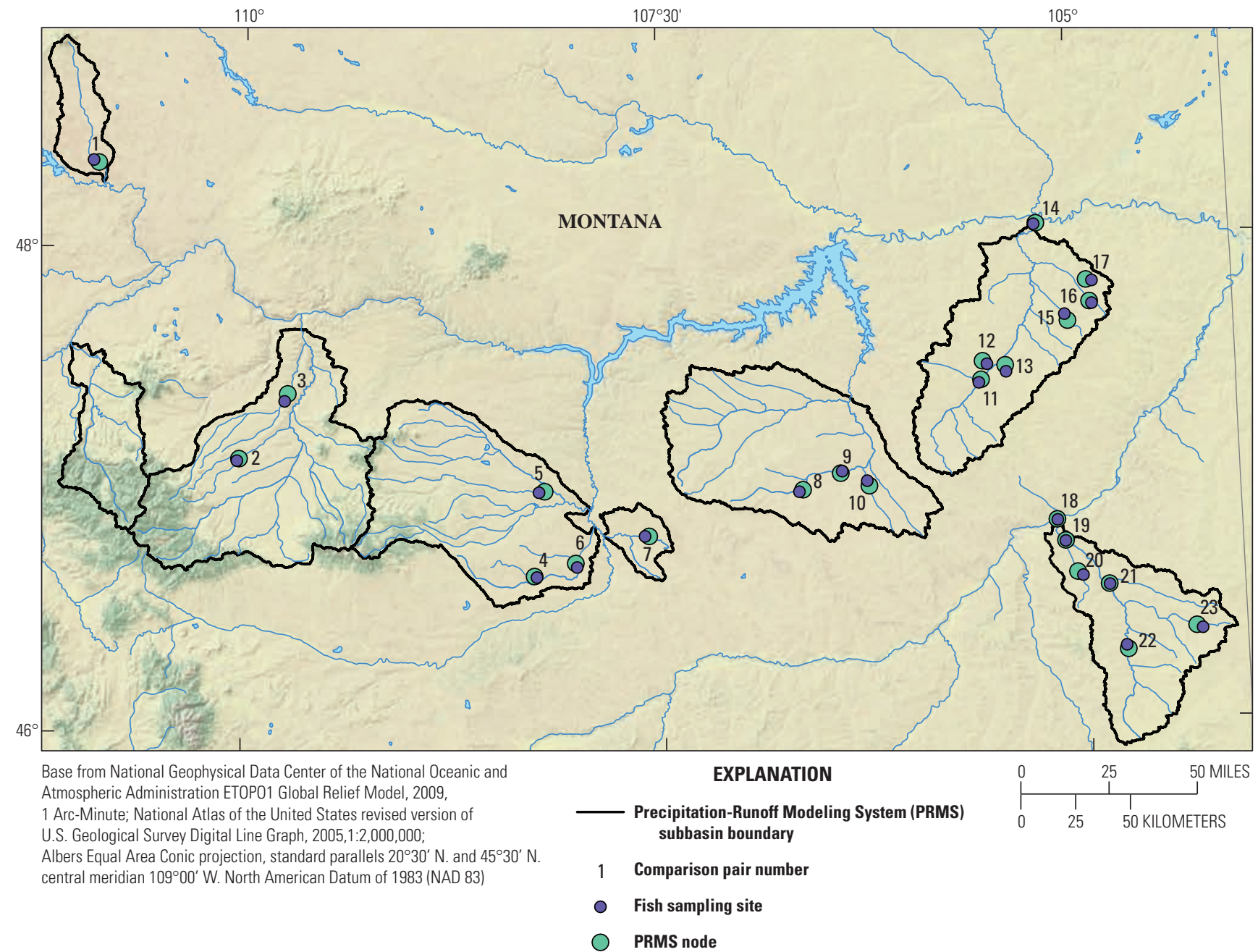

Figure 6. Locations of fish sampling sites and corresponding Precipitation-Runoff Modeling System nodes used for comparison of predicted and simulated streamflow characteristic values.

predicted at fish sampling sites and streamflow characteristics calculated at streamflow-gaging stations is presented as the mean absolute percent error (Hanke and Reitsch, 1995). The average mean absolute percent error was about 73 percent at the 21 comparison sites.

\section{Limitations of the Random Forest Regression Analyses}

Although RF regression analysis is better than least squares regression methods at extrapolating predictions for observations with predictor variable values outside the statistical ranges of the training data (Prasad and others, 2006), predictions made for fish sampling sites with drainage basin characteristic values outside the range of the drainage basin characteristic values for the PRMS nodes might not be reliable.
Potential effects of anthropogenic influences, such as landcover change, irrigation practices, and diversions/reservoir operations, are not accounted for in baseline or future simulated streamflow. These factors might substantially affect streamflow and should be considered as much as possible when using the future simulated and predicted streamflow.

The PRMS models were calibrated in seven basins that occupy part of the overall study area. Because of the poor spatial distribution of adequate calibration data from USGS streamflow-gaging stations, the data generated from the PRMS models were used to develop RF regression models that predicted streamflow characteristics at fish sampling sites far outside of the PRMS node drainage basins (fig. 1); thus, it is possible that large uncertainty is introduced. This uncertainty should be considered when using streamflow estimates at fish sampling sites outside the PRMS node drainage basins.

The simulated streamflow data published by Chase and others (2016) and used in this study as simulated streamflow have limitations that also should be considered. Those limitations are described in detail by Chase and others (2016). 
Table 4. Mean relative percent difference and coefficient of determination for all predictive models for each comparison pai [mi², square mile; R2, coefficient of determination; PRMS, Precipitation-Runoff Modeling System]

\begin{tabular}{|c|c|c|c|c|c|c|c|c|c|c|c|c|c|c|c|c|c|c|c|c|}
\hline \multirow[b]{2}{*}{$\begin{array}{c}\text { Comparison } \\
\text { number } \\
\text { (fig. 6) }\end{array}$} & \multirow[b]{2}{*}{ Basin } & \multirow[b]{2}{*}{ Source } & \multirow[b]{2}{*}{ Site identifier } & \multirow[b]{2}{*}{$\begin{array}{c}\text { Drainage } \\
\text { area } \\
\left(m^{2}\right)=\end{array}$} & \multicolumn{2}{|c|}{ Baseline conditions } & \multicolumn{2}{|c|}{ ECHAM5 2030s } & \multicolumn{2}{|c|}{ ECHAM5 2055s } & \multicolumn{2}{|c|}{ ECHAM5 2080s } & \multicolumn{2}{|c|}{ GENMOM 2030s } & \multicolumn{2}{|c|}{ GENMOM 2055s } & \multicolumn{2}{|c|}{ GENMOM 2080s } & \multicolumn{2}{|c|}{ GFDL 2055s } \\
\hline & & & & & $\begin{array}{c}\text { Mean } \\
\text { relative } \\
\text { percent } \\
\text { difference }\end{array}$ & $R^{2}$ & $\begin{array}{c}\text { Mean } \\
\text { relative } \\
\text { percent } \\
\text { difference }\end{array}$ & $R^{2}$ & $\begin{array}{c}\text { Mean } \\
\text { relative } \\
\text { percent } \\
\text { difference }\end{array}$ & $R^{2}$ & $\begin{array}{c}\text { Mean } \\
\text { relative } \\
\text { percent } \\
\text { difference }\end{array}$ & $R^{2}$ & $\begin{array}{c}\text { Mean } \\
\text { relative } \\
\text { percent } \\
\text { difference }\end{array}$ & $R^{2}$ & $\begin{array}{c}\text { Mean } \\
\text { relative } \\
\text { percent } \\
\text { difference }\end{array}$ & $R^{2}$ & $\begin{array}{c}\text { Mean } \\
\text { relative } \\
\text { percent } \\
\text { difference }\end{array}$ & $R^{2}$ & $\begin{array}{c}\text { Mean } \\
\text { relative } \\
\text { percent } \\
\text { difference }\end{array}$ & $R^{2}$ \\
\hline 1 & $\begin{array}{l}\text { Cottonwood Creek } \\
\text { Cottonwood Creek }\end{array}$ & $\begin{array}{l}\text { Fish sampling site } \\
\text { PRMS node }\end{array}$ & $\begin{array}{l}\text { Cottonwood Creek } 8 \\
\text { Segment } 5\end{array}$ & $\begin{array}{l}363 \\
372\end{array}$ & 59.34 & 0.64 & 53.74 & 0.71 & 48.50 & 0.65 & 50.90 & 0.81 & 64.49 & 0.64 & 54.40 & 0.70 & 64.55 & 0.79 & 54.40 & 0.72 \\
\hline 2 & $\begin{array}{l}\text { Ootonwooo Creek } \\
\text { Judith River } \\
\text { Judith River }\end{array}$ & $\begin{array}{l}\text { Fish sampling site } \\
\text { PRMS node }\end{array}$ & $\begin{array}{l}\text { Segments } 5 \\
\text { Sage Creek } 3 \\
\text { Segment } 7\end{array}$ & $\begin{array}{r}3 / 2 \\
96 \\
98\end{array}$ & 57.63 & 0.70 & 58.47 & 0.81 & 59.99 & 0.63 & 63.39 & 0.77 & 59.43 & 0.69 & 67.78 & 0.68 & 63.93 & 0.55 & 67.78 & 0.54 \\
\hline 3 & $\begin{array}{l}\text { Judith River } \\
\text { Judith River }\end{array}$ & $\begin{array}{l}\text { Fish sampling site } \\
\text { PRMS node }\end{array}$ & $\begin{array}{l}\text { Wolf Creek A1 } \\
\text { Segment } 9\end{array}$ & $\begin{array}{l}380 \\
401\end{array}$ & 62.63 & 0.85 & 69.05 & 0.84 & 62.13 & 0.74 & 61.81 & 0.79 & 64.99 & 0.85 & 78.92 & 0.86 & 68.14 & 0.89 & 78.92 & 0.67 \\
\hline 4 & $\begin{array}{l}\text { Middle Musselshell River } \\
\text { Middle Musselshell River }\end{array}$ & $\begin{array}{l}\text { Fish sampling site } \\
\text { PRMS node }\end{array}$ & $\begin{array}{l}\text { Little Wall Creek } 2 \\
\text { Segment } 16\end{array}$ & $\begin{array}{r}103 \\
98\end{array}$ & 49.20 & 0.67 & 39.39 & 0.85 & 40.84 & 0.87 & 38.61 & 0.94 & 50.84 & 0.70 & 47.11 & 0.95 & 46.91 & 0.95 & 47.11 & 0.95 \\
\hline 5 & $\begin{array}{l}\text { Middle Musselshell River } \\
\text { Middle Musselshell River }\end{array}$ & $\begin{array}{l}\text { Fish sampling site } \\
\text { PRMS node }\end{array}$ & $\begin{array}{l}\text { McDonald Creek A1 } \\
\text { Segment } 58\end{array}$ & $\begin{array}{l}450 \\
453\end{array}$ & 75.85 & 0.66 & 68.52 & 0.79 & 74.51 & 0.66 & 69.84 & 0.74 & 79.67 & 0.65 & 77.68 & 0.69 & 83.40 & 0.62 & 77.68 & 0.65 \\
\hline 6 & $\begin{array}{l}\text { Middle Musselshell River } \\
\text { Middle Musselshell River }\end{array}$ & $\begin{array}{l}\text { Fish sampling site } \\
\text { PRMS node }\end{array}$ & $\begin{array}{l}\text { North Willow Creek C1 } \\
\text { Segment } 14\end{array}$ & $\begin{array}{l}373 \\
376\end{array}$ & 73.71 & 0.68 & 62.48 & 0.77 & 68.07 & 0.66 & 62.72 & 0.80 & 75.43 & 0.70 & 70.16 & 0.77 & 79.04 & 0.77 & 70.16 & 0.75 \\
\hline 7 & $\begin{array}{l}\text { Middle Musselshell River } \\
\text { Middle Musselshell River }\end{array}$ & $\begin{array}{l}\text { Fish sampling site } \\
\text { PRMS node }\end{array}$ & $\begin{array}{l}\text { Big Breed Creek } 1 \\
\text { Segment } 25\end{array}$ & $\begin{array}{l}39 \\
66\end{array}$ & 52.50 & 0.75 & 56.85 & 0.81 & 63.87 & 0.87 & 68.67 & 0.85 & 52.84 & 0.75 & 55.42 & 0.85 & 56.63 & 0.86 & 55.42 & 0.79 \\
\hline 8 & $\begin{array}{l}\text { Little Dry Creek } \\
\text { Little Dry Creek }\end{array}$ & $\begin{array}{l}\text { Fish sampling site } \\
\text { PRMS node }\end{array}$ & $\begin{array}{l}\text { Little Dry Creek } 3 \\
\text { Segment } 121\end{array}$ & $\begin{array}{l}173 \\
186\end{array}$ & 28.74 & 0.97 & 34.56 & 0.94 & 37.62 & 0.87 & 36.14 & 0.93 & 25.00 & 0.96 & 27.02 & 0.93 & 18.77 & 0.92 & 27.02 & 0.86 \\
\hline 9 & $\begin{array}{l}\text { Little Dry Creek } \\
\text { Little Dry Creek }\end{array}$ & $\begin{array}{l}\text { Fish sampling site } \\
\text { PRMS node }\end{array}$ & $\begin{array}{l}\text { Little Dry Creek B1 } \\
\text { Segment } 112\end{array}$ & $\begin{array}{l}402 \\
401\end{array}$ & 30.87 & 0.97 & 22.47 & 0.93 & 29.17 & 0.88 & 23.49 & 0.92 & 28.32 & 0.97 & 20.49 & 0.89 & 24.15 & 0.95 & 20.49 & 0.92 \\
\hline 10 & $\begin{array}{l}\text { Little Dry Creek } \\
\text { Little Dry Creek }\end{array}$ & $\begin{array}{l}\text { Fish sampling site } \\
\text { PRMS node }\end{array}$ & $\begin{array}{l}\text { U All Creek } 1 \\
\text { Segment } 122\end{array}$ & $\begin{array}{l}115 \\
107\end{array}$ & 37.10 & 0.99 & 30.81 & 0.96 & 27.33 & 0.89 & 24.83 & 0.92 & 35.55 & 1.00 & 23.87 & 0.91 & 34.64 & 0.88 & 23.87 & 0.85 \\
\hline 11 & $\begin{array}{l}\text { Redwater River } \\
\text { Redwater River }\end{array}$ & $\begin{array}{l}\text { Fish sampling site } \\
\text { PRMS node }\end{array}$ & $\begin{array}{l}\text { Redwater River } 6 \\
\text { Segment } 27\end{array}$ & $\begin{array}{l}551 \\
553\end{array}$ & 31.78 & 0.97 & 30.51 & 0.94 & 25.03 & 0.97 & 26.57 & 0.83 & 35.49 & 0.97 & 32.06 & 0.97 & 28.78 & 0.89 & 32.06 & 0.93 \\
\hline 12 & $\begin{array}{l}\text { Redwater River } \\
\text { Redwater River }\end{array}$ & $\begin{array}{l}\text { Fish sampling site } \\
\text { PRMS node }\end{array}$ & $\begin{array}{l}\text { Lost Creek } 3 \\
\text { Segment } 14\end{array}$ & $\begin{array}{l}48 \\
41\end{array}$ & 16.42 & 1.00 & 21.20 & 0.98 & 18.64 & 0.99 & 24.18 & 0.73 & 12.75 & 1.00 & 16.66 & 0.99 & 19.68 & 0.93 & 16.66 & 0.90 \\
\hline 13 & $\begin{array}{l}\text { Redwater River } \\
\text { Redwater River }\end{array}$ & $\begin{array}{l}\text { Fish sampling site } \\
\text { PRMS node }\end{array}$ & $\begin{array}{l}\text { Cottonwood Creek } 11 \\
\text { Segment } 25\end{array}$ & $\begin{array}{l}38 \\
74\end{array}$ & 54.30 & 0.98 & 54.36 & 0.80 & 52.52 & 0.92 & 52.40 & 0.91 & 54.59 & 0.98 & 56.39 & 0.97 & 51.40 & 0.92 & 56.39 & 0.98 \\
\hline 14 & $\begin{array}{l}\text { Redwater River } \\
\text { Redwater River }\end{array}$ & $\begin{array}{l}\text { Fish sampling site } \\
\text { PRMS node }\end{array}$ & $\begin{array}{l}\text { Redwater River } 7 \\
\text { Segment } 2\end{array}$ & $\begin{array}{l}2,112 \\
2,115\end{array}$ & 96.65 & 0.96 & 88.29 & 0.95 & 91.97 & 0.98 & 87.80 & 0.79 & 99.54 & 0.96 & 93.35 & 0.97 & 101.48 & 0.73 & 93.35 & 0.95 \\
\hline 15 & $\begin{array}{l}\text { Redwater River } \\
\text { Redwater River }\end{array}$ & $\begin{array}{l}\text { Fish sampling site } \\
\text { PRMS node }\end{array}$ & $\begin{array}{l}\text { South Fork Lisk Creek } 1 \\
\text { Segment } 11\end{array}$ & $\begin{array}{l}24 \\
19\end{array}$ & 27.09 & 0.99 & 27.08 & 0.98 & 25.90 & 0.96 & 25.29 & 0.80 & 25.84 & 1.00 & 23.99 & 0.97 & 27.05 & 0.82 & 23.99 & 0.98 \\
\hline 16 & $\begin{array}{l}\text { Redwater River } \\
\text { Redwater River }\end{array}$ & $\begin{array}{l}\text { Fish sampling site } \\
\text { PRMS node }\end{array}$ & $\begin{array}{l}\text { North Fork East Redwater Creek } 1 \\
\text { Segment } 18\end{array}$ & $\begin{array}{l}23 \\
27\end{array}$ & 21.08 & 0.97 & 27.03 & 0.94 & 23.63 & 0.97 & 21.82 & 0.62 & 19.41 & 0.97 & 23.20 & 0.96 & 19.42 & 0.95 & 23.20 & 0.86 \\
\hline 17 & $\begin{array}{l}\text { Redwater River } \\
\text { Redwater River }\end{array}$ & $\begin{array}{l}\text { Fish sampling site } \\
\text { PRMS node }\end{array}$ & $\begin{array}{l}\text { East Redwater Creek } 1 \\
\text { Segment } 22\end{array}$ & $\begin{array}{l}35 \\
35\end{array}$ & 20.94 & 0.99 & 20.35 & 0.97 & 16.72 & 0.99 & 19.67 & 0.70 & 19.24 & 0.99 & 20.32 & 0.98 & 18.84 & 0.89 & 20.32 & 0.86 \\
\hline 18 & $\begin{array}{l}\text { O'Fallon Creek } \\
\text { O'Fallon Creek }\end{array}$ & $\begin{array}{l}\text { Fish sampling site } \\
\text { PRMS node }\end{array}$ & $\begin{array}{l}\text { O'Fallon Creek B1 } \\
\text { Segment } 6\end{array}$ & $\begin{array}{l}1,578 \\
1,578\end{array}$ & 76.30 & 0.93 & 68.80 & 0.93 & 78.46 & 0.97 & 75.96 & 0.95 & 73.62 & 0.94 & 68.05 & 0.92 & 82.33 & 0.92 & 68.05 & 0.96 \\
\hline 19 & $\begin{array}{l}\text { O'Fallon Creek } \\
\text { O'Fallon Creek }\end{array}$ & $\begin{array}{l}\text { Fish sampling site } \\
\text { PRMS node }\end{array}$ & $\begin{array}{l}\text { Whitney Creek C1 } \\
\text { Segment } 1\end{array}$ & $\begin{array}{l}130 \\
130\end{array}$ & 19.34 & 0.98 & 22.56 & 0.93 & 21.55 & 0.97 & 19.07 & 0.96 & 22.69 & 0.92 & 25.01 & 0.95 & 23.67 & 0.97 & 25.01 & 0.99 \\
\hline 20 & $\begin{array}{l}\text { O'Fallon Creek } \\
\text { O'Fallon Creek }\end{array}$ & $\begin{array}{l}\text { Fish sampling site } \\
\text { PRMS node }\end{array}$ & $\begin{array}{l}\text { Whitney Creek A2 } \\
\text { Segment } 4\end{array}$ & $\begin{array}{l}35 \\
61\end{array}$ & 36.26 & 0.97 & 40.22 & 0.95 & 40.50 & 0.93 & 38.25 & 0.97 & 36.04 & 0.91 & 41.22 & 0.94 & 37.94 & 0.94 & 41.22 & 0.97 \\
\hline 21 & $\begin{array}{l}\text { O'Fallon Creek } \\
\text { O'Fallon Creek }\end{array}$ & $\begin{array}{l}\text { Fish sampling site } \\
\text { PRMS node }\end{array}$ & $\begin{array}{l}\text { Pennel Creek B1 } \\
\text { Segment } 7\end{array}$ & $\begin{array}{l}215 \\
215\end{array}$ & 13.99 & 0.98 & 16.63 & 0.99 & 15.26 & 0.99 & 15.07 & 0.99 & 14.41 & 0.99 & 19.87 & 0.98 & 14.86 & 0.99 & 19.87 & 0.99 \\
\hline 22 & $\begin{array}{l}\text { O'Fallon Creek } \\
\text { O'Fallon Creek }\end{array}$ & $\begin{array}{l}\text { Fish sampling site } \\
\text { PRMS node }\end{array}$ & $\begin{array}{l}\text { O'Fallon Creek } 7 \\
\text { Segment } 19\end{array}$ & $\begin{array}{l}489 \\
485\end{array}$ & 22.34 & 0.96 & 23.39 & 0.95 & 19.81 & 0.98 & 17.20 & 0.98 & 19.22 & 0.99 & 23.84 & 0.98 & 18.85 & 0.99 & 23.84 & 0.98 \\
\hline 23 & $\begin{array}{l}\text { O'Fallon Creek } \\
\text { O'Fallon Creek }\end{array}$ & $\begin{array}{l}\text { Fish sampling site } \\
\text { PRMS node }\end{array}$ & $\begin{array}{l}\text { Sandstone Creek } 4 \\
\text { Segment } 18\end{array}$ & $\begin{array}{l}52 \\
55\end{array}$ & 22.28 & 0.97 & 28.59 & 0.95 & 24.14 & 0.96 & 20.87 & 0.96 & 16.67 & 0.99 & 16.68 & 0.99 & 21.32 & 0.98 & 16.68 & 0.99 \\
\hline
\end{tabular}




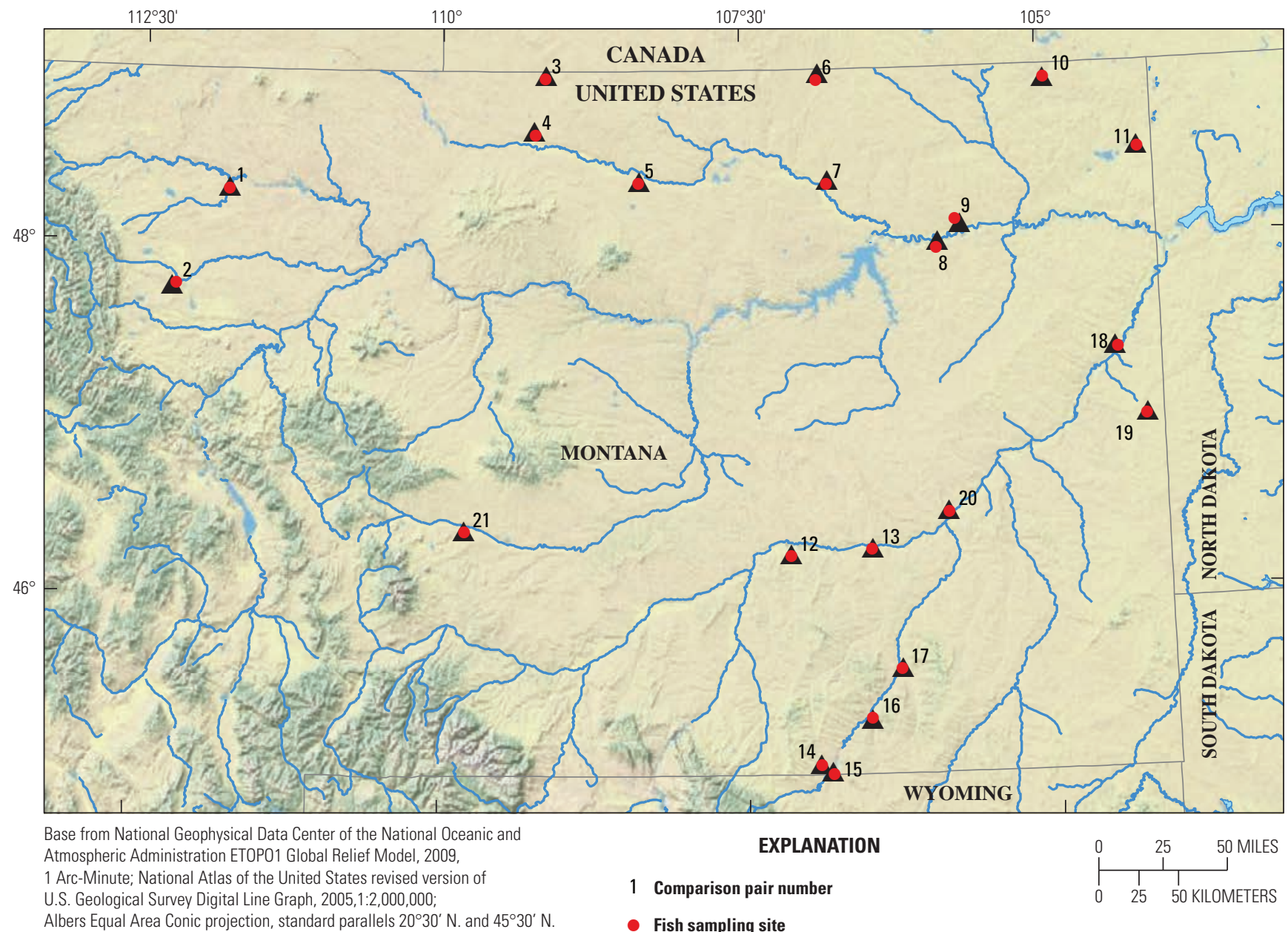

Alhers Equal Area Conic projection, standard parallels $20^{\circ} 30^{\prime} \mathrm{N}$ and $45^{\circ} 30^{\prime} \mathrm{N}$ central meridian $109^{\circ} 00^{\prime}$ W. North American Datum of 1983 (NAD 83)

U.S. Geological Survey streamflow-gaging station

Figure 7. Location of fish sampling sites and corresponding U.S. Geological Survey streamflow-gaging stations used for comparison of predicted and observed streamflow characteristic values. 
Table 5. Mean relative percent difference for each prediction model calculated from all comparison pairs.

\begin{tabular}{|c|c|c|c|c|c|c|c|c|}
\hline \multirow{2}{*}{$\begin{array}{c}\text { Prediction } \\
\text { model }\end{array}$} & \multicolumn{8}{|c|}{ Mean relative percent difference } \\
\hline & $\begin{array}{c}\text { Baseline } \\
\text { conditions }\end{array}$ & $\begin{array}{c}\text { ECHAM5 } \\
2030 s\end{array}$ & $\begin{array}{c}\text { ECHAM5 } \\
2055 s\end{array}$ & $\begin{array}{c}\text { ECHAM5 } \\
2080 \mathrm{~s}\end{array}$ & $\begin{array}{l}\text { GENMOM } \\
\text { 2030s }\end{array}$ & $\begin{array}{l}\text { GENMOM } \\
2055 \mathrm{~s}\end{array}$ & $\begin{array}{l}\text { GENMOM } \\
\text { 2080s }\end{array}$ & GFDL 2055s \\
\hline M1p25 & 38.11 & 33.90 & 48.38 & 50.17 & 37.61 & 36.16 & 34.90 & 33.39 \\
\hline M2p25 & 33.76 & 31.93 & 42.95 & 41.89 & 32.16 & 32.70 & 32.46 & 31.30 \\
\hline M3p25 & 35.14 & 33.85 & 38.78 & 38.47 & 35.80 & 34.49 & 37.76 & 33.93 \\
\hline M4p25 & 43.98 & 42.58 & 38.43 & 37.35 & 47.08 & 46.83 & 45.65 & 39.64 \\
\hline M5p25 & 52.32 & 51.78 & 42.34 & 41.19 & 53.61 & 53.29 & 52.65 & 52.83 \\
\hline M6p25 & 46.91 & 46.47 & 43.01 & 43.19 & 47.98 & 46.92 & 46.56 & 45.50 \\
\hline M7p25 & 44.35 & 44.20 & 32.04 & 31.78 & 45.34 & 43.94 & 43.84 & 44.14 \\
\hline M8p25 & 39.30 & 39.60 & 40.37 & 38.88 & 39.35 & 40.16 & 41.34 & 38.47 \\
\hline M9p25 & 37.78 & 38.44 & 31.37 & 32.26 & 37.16 & 38.23 & 37.95 & 39.19 \\
\hline M10p25 & 42.58 & 40.75 & 40.24 & 40.36 & 40.41 & 35.41 & 37.85 & 38.69 \\
\hline M11p25 & 50.32 & 50.35 & 43.53 & 42.09 & 48.25 & 44.30 & 46.54 & 46.05 \\
\hline M12p25 & 45.36 & 46.05 & 50.06 & 44.54 & 44.15 & 40.59 & 42.82 & 39.90 \\
\hline M1p50 & 34.72 & 31.66 & 42.98 & 43.41 & 34.92 & 33.06 & 35.03 & 31.05 \\
\hline M2p50 & 34.64 & 32.00 & 45.43 & 44.18 & 35.60 & 33.51 & 33.27 & 32.29 \\
\hline М3p50 & 39.43 & 41.36 & 45.11 & 39.04 & 46.11 & 39.90 & 47.66 & 47.46 \\
\hline M4p50 & 42.57 & 45.34 & 37.25 & 33.73 & 51.10 & 51.45 & 54.62 & 45.19 \\
\hline M5p50 & 56.94 & 56.12 & 46.74 & 44.86 & 60.29 & 61.04 & 60.07 & 60.94 \\
\hline M6p50 & 46.60 & 46.17 & 44.58 & 43.44 & 47.47 & 46.39 & 47.22 & 47.26 \\
\hline MH7p50 & 53.36 & 51.83 & 48.51 & 47.02 & 53.07 & 55.12 & 57.71 & 56.25 \\
\hline M8p50 & 55.02 & 57.40 & 53.62 & 50.44 & 54.08 & 56.08 & 57.47 & 55.18 \\
\hline M9p50 & 35.77 & 38.68 & 31.98 & 29.20 & 34.24 & 35.53 & 35.48 & 38.48 \\
\hline M10p50 & 42.42 & 40.42 & 43.69 & 39.37 & 40.23 & 37.17 & 38.61 & 41.92 \\
\hline M11p50 & 41.04 & 39.94 & 36.00 & 31.09 & 38.02 & 34.71 & 37.55 & 35.37 \\
\hline M12p50 & 37.70 & 36.25 & 40.88 & 34.37 & 36.46 & 30.42 & 31.57 & 31.29 \\
\hline M1p75 & 40.92 & 32.08 & 47.12 & 45.19 & 40.83 & 38.00 & 40.33 & 34.92 \\
\hline M2p75 & 40.65 & 45.04 & 42.27 & 40.80 & 41.67 & 37.55 & 32.73 & 33.06 \\
\hline М3p75 & 26.02 & 35.56 & 53.49 & 54.67 & 26.23 & 40.77 & 44.13 & 44.64 \\
\hline M4p75 & 39.76 & 38.50 & 39.76 & 40.25 & 47.35 & 43.48 & 48.40 & 40.70 \\
\hline M5p75 & 50.58 & 37.05 & 48.56 & 49.21 & 56.75 & 56.78 & 59.19 & 62.26 \\
\hline M6p75 & 51.79 & 52.23 & 54.26 & 56.77 & 55.08 & 55.13 & 57.41 & 55.26 \\
\hline M7p75 & 44.72 & 44.46 & 43.21 & 40.63 & 43.40 & 43.62 & 45.20 & 46.16 \\
\hline M8p75 & 45.48 & 47.36 & 48.43 & 44.88 & 46.01 & 47.03 & 44.94 & 46.48 \\
\hline M9p75 & 52.84 & 52.96 & 41.45 & 36.58 & 54.86 & 53.27 & 54.07 & 59.72 \\
\hline M10p75 & 56.49 & 55.91 & 38.48 & 39.09 & 52.03 & 51.43 & 54.13 & 58.73 \\
\hline M11p75 & 39.36 & 38.67 & 41.40 & 40.65 & 38.44 & 36.64 & 36.53 & 41.56 \\
\hline M12p75 & 47.08 & 42.66 & 49.34 & 45.73 & 47.01 & 41.21 & 44.99 & 45.80 \\
\hline M1mean & 36.40 & 60.52 & 28.02 & 40.32 & 31.10 & 42.29 & 41.28 & 31.32 \\
\hline M2mean & 43.14 & 39.05 & 47.83 & 43.56 & 46.47 & 36.53 & 29.78 & 34.30 \\
\hline M3mean & 31.75 & 37.92 & 40.29 & 55.45 & 31.95 & 43.79 & 39.52 & 30.81 \\
\hline M4mean & 42.72 & 45.79 & 34.19 & 32.70 & 42.35 & 45.67 & 44.22 & 37.34 \\
\hline M5mean & 39.14 & 29.31 & 40.97 & 46.58 & 49.45 & 43.84 & 53.11 & 37.48 \\
\hline M6mean & 40.97 & 40.43 & 44.12 & 44.68 & 40.47 & 45.34 & 43.47 & 43.89 \\
\hline M7mean & 46.90 & 45.60 & 51.51 & 48.33 & 42.31 & 46.34 & 44.61 & 54.80 \\
\hline M8mean & 47.58 & 40.88 & 61.17 & 43.33 & 53.63 & 51.70 & 50.06 & 52.60 \\
\hline M9mean & 50.29 & 52.58 & 36.65 & 33.45 & 53.61 & 51.20 & 52.01 & 56.32 \\
\hline
\end{tabular}


Table 5. Mean relative percent difference for each prediction model calculated from all comparison pairs.-Continued

\begin{tabular}{|c|c|c|c|c|c|c|c|c|}
\hline \multirow{2}{*}{$\begin{array}{c}\text { Prediction } \\
\text { model }\end{array}$} & \multicolumn{8}{|c|}{ Mean relative percent difference } \\
\hline & $\begin{array}{c}\text { Baseline } \\
\text { conditions }\end{array}$ & $\begin{array}{c}\text { ECHAM5 } \\
2030 \mathrm{~s}\end{array}$ & $\begin{array}{c}\text { ECHAM5 } \\
2055 s\end{array}$ & $\begin{array}{c}\text { ECHAM5 } \\
2080 s\end{array}$ & $\begin{array}{c}\text { GENMOM } \\
2030 \mathrm{~s}\end{array}$ & $\begin{array}{c}\text { GENMOM } \\
2055 \mathrm{~s}\end{array}$ & $\begin{array}{l}\text { GENMOM } \\
\text { 2080s }\end{array}$ & GFDL 2055s \\
\hline M10mean & 50.18 & 51.04 & 33.07 & 35.09 & 47.90 & 48.04 & 47.91 & 54.10 \\
\hline M11mean & 49.19 & 47.65 & 39.72 & 38.47 & 46.72 & 45.17 & 46.46 & 51.34 \\
\hline M12mean & 32.67 & 28.78 & 35.28 & 33.18 & 31.22 & 29.27 & 32.32 & 37.25 \\
\hline S1minp25 & 35.18 & 31.84 & 40.95 & 38.06 & 34.61 & 32.86 & 32.10 & 31.62 \\
\hline S2minp25 & 46.51 & 44.35 & 31.85 & 31.52 & 49.73 & 49.66 & 46.74 & 42.22 \\
\hline S3minp25 & 38.37 & 37.80 & 31.81 & 30.77 & 37.59 & 39.00 & 38.25 & 37.65 \\
\hline S4minp25 & 36.10 & 35.06 & 34.13 & 33.37 & 35.65 & 31.95 & 32.48 & 30.36 \\
\hline S1minp50 & 35.73 & 32.60 & 41.31 & 38.10 & 34.65 & 32.83 & 34.08 & 31.71 \\
\hline S2minp50 & 40.49 & 40.57 & 39.14 & 36.91 & 43.79 & 45.87 & 46.14 & 39.55 \\
\hline S3minp50 & 52.64 & 54.10 & 47.65 & 45.72 & 53.24 & 54.74 & 54.60 & 55.32 \\
\hline S4minp50 & 37.25 & 35.95 & 36.92 & 32.18 & 36.43 & 30.87 & 31.81 & 30.86 \\
\hline S1maxp75 & 28.74 & 41.66 & 47.46 & 41.74 & 33.83 & 39.50 & 38.51 & 38.32 \\
\hline S2maxp75 & 53.08 & 40.53 & 49.47 & 47.94 & 60.63 & 57.76 & 60.68 & 59.16 \\
\hline S3maxp75 & 44.43 & 45.01 & 46.64 & 42.50 & 43.07 & 43.56 & 45.12 & 46.39 \\
\hline S4maxp75 & 56.36 & 55.63 & 41.98 & 40.76 & 55.12 & 51.94 & 54.01 & 58.65 \\
\hline S1maxmean & 40.69 & 39.58 & 30.29 & 52.46 & 37.35 & 32.47 & 33.75 & 31.53 \\
\hline S2maxmean & 41.01 & 33.83 & 43.11 & 38.68 & 36.58 & 44.28 & 47.35 & 36.10 \\
\hline S3maxmean & 47.15 & 45.75 & 53.48 & 43.15 & 42.68 & 35.68 & 39.71 & 47.47 \\
\hline S4maxmean & 39.55 & 41.91 & 31.59 & 34.85 & 37.36 & 39.89 & 39.37 & 45.83 \\
\hline Aminp25 & 34.39 & 32.86 & 35.94 & 33.29 & 33.93 & 27.84 & 28.92 & 28.02 \\
\hline Aminp50 & 37.16 & 36.02 & 39.84 & 37.75 & 35.49 & 30.72 & 32.63 & 30.27 \\
\hline Amaxp 75 & 41.49 & 46.54 & 36.15 & 40.70 & 47.65 & 51.79 & 59.86 & 58.05 \\
\hline Amaxmean & 33.12 & 30.65 & 30.24 & 32.45 & 30.12 & 30.14 & 38.25 & 36.96 \\
\hline S1p25 & 40.28 & 37.55 & 51.93 & 52.46 & 39.98 & 39.60 & 41.15 & 38.34 \\
\hline S2p25 & 52.09 & 52.24 & 50.72 & 50.55 & 54.87 & 53.38 & 53.30 & 52.59 \\
\hline S3p25 & 51.50 & 50.09 & 47.82 & 46.71 & 51.61 & 52.17 & 53.02 & 52.28 \\
\hline S4p25 & 50.53 & 50.99 & 49.21 & 47.59 & 48.82 & 44.28 & 46.27 & 46.00 \\
\hline S1p50 & 34.28 & 34.29 & 42.97 & 41.56 & 36.94 & 32.69 & 36.81 & 34.09 \\
\hline S2p50 & 45.76 & 45.96 & 40.03 & 38.86 & 48.17 & 48.59 & 49.36 & 47.18 \\
\hline S3p50 & 52.81 & 51.73 & 48.90 & 44.75 & 52.90 & 53.54 & 55.14 & 53.93 \\
\hline S4p50 & 37.07 & 34.94 & 35.95 & 32.33 & 36.43 & 31.02 & 32.18 & 33.56 \\
\hline S1p75 & 29.12 & 40.82 & 42.75 & 39.99 & 29.84 & 34.57 & 35.58 & 32.75 \\
\hline S2p75 & 50.06 & 44.58 & 49.92 & 49.27 & 56.21 & 54.73 & 57.86 & 56.06 \\
\hline S3p75 & 52.23 & 48.59 & 52.99 & 45.72 & 51.95 & 51.19 & 53.11 & 54.31 \\
\hline S4p75 & 41.60 & 39.40 & 40.03 & 40.54 & 39.07 & 37.28 & 38.61 & 43.52 \\
\hline S1mean & 34.57 & 39.65 & 30.64 & 50.00 & 33.40 & 35.04 & 35.62 & 27.26 \\
\hline S2mean & 79.84 & 29.88 & 42.69 & 41.31 & 40.42 & 43.19 & 48.76 & 36.00 \\
\hline S3mean & 44.52 & 39.56 & 49.84 & 42.66 & 44.65 & 39.91 & 43.08 & 41.80 \\
\hline S4mean & 38.06 & 37.53 & 32.21 & 35.25 & 36.32 & 36.72 & 37.57 & 42.83 \\
\hline Ap25 & 41.64 & 40.95 & 36.81 & 36.69 & 42.04 & 40.74 & 41.20 & 39.62 \\
\hline Ap50 & 42.71 & 41.54 & 40.05 & 37.32 & 44.15 & 42.08 & 43.65 & 41.58 \\
\hline Ap75 & 45.30 & 45.22 & 46.89 & 47.15 & 49.18 & 47.50 & 53.15 & 51.03 \\
\hline Amean & 25.99 & 34.45 & 29.01 & 36.16 & 23.33 & 32.89 & 40.27 & 30.80 \\
\hline Arange & 30.59 & 34.19 & 38.45 & 33.27 & 28.58 & 32.21 & 38.37 & 37.51 \\
\hline
\end{tabular}


Table 6. Mean absolute percent error calculated by comparing monthly mean streamflow values predicted at select fish sampling sites and monthly mean streamflow values calculated at nearby U.S. Geological Survey streamflow-gaging stations.

[USGS, U.S. Geological Survey; --, not applicable]

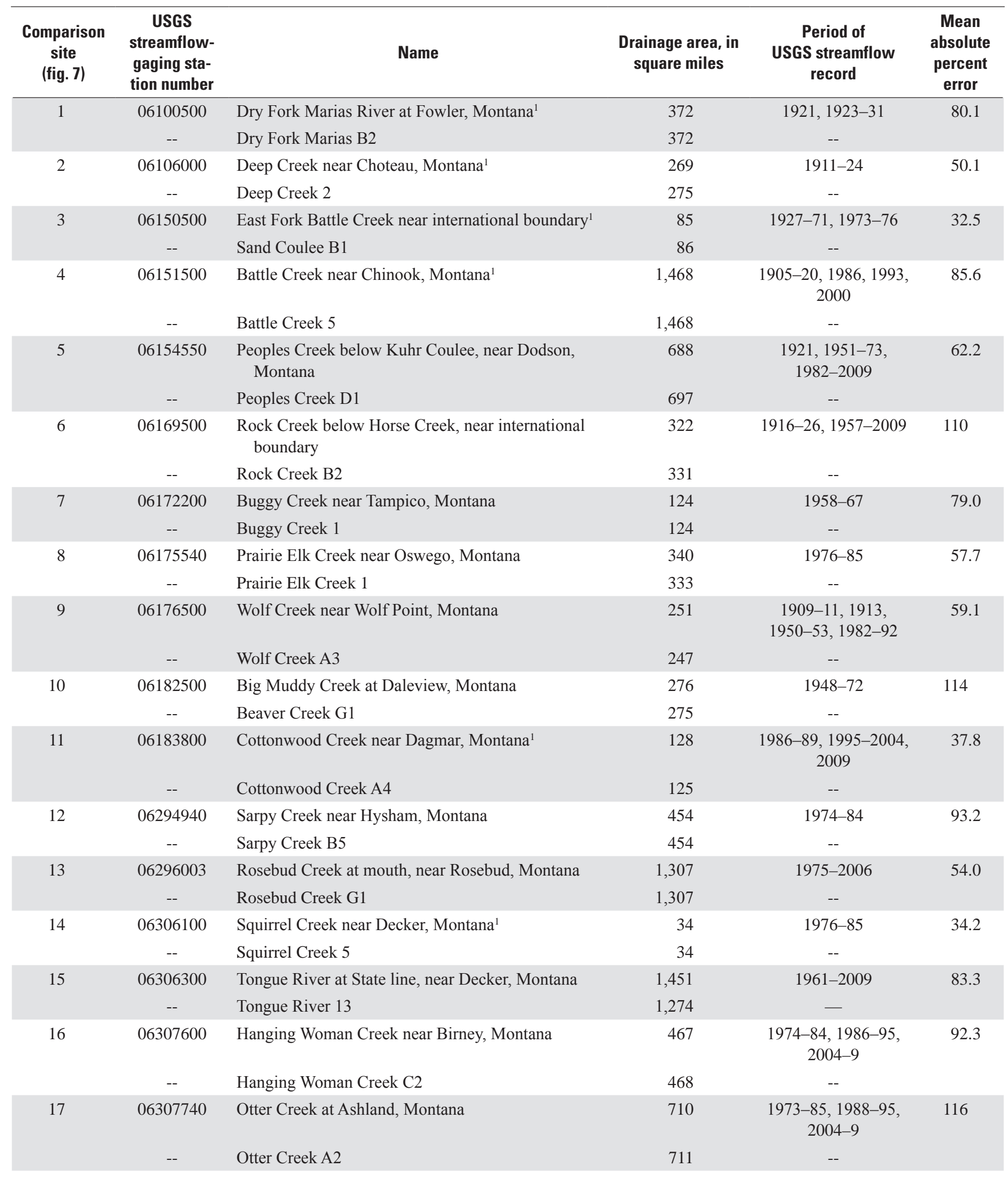


Table 6. Mean absolute percent error calculated by comparing monthly mean streamflow values predicted at select fish sampling sites and monthly mean streamflow values calculated at nearby U.S. Geological Survey streamflow-gaging stations.—Continued

[USGS, U.S. Geological Survey; --, not applicable]

\begin{tabular}{|c|c|c|c|c|c|}
\hline $\begin{array}{l}\text { Comparison } \\
\text { site } \\
\text { (fig. 7) }\end{array}$ & $\begin{array}{c}\text { USGS } \\
\text { streamflow- } \\
\text { gaging sta- } \\
\text { tion number }\end{array}$ & Name & $\begin{array}{l}\text { Drainage area, in } \\
\text { square miles }\end{array}$ & $\begin{array}{l}\text { Period of } \\
\text { USGS streamflow } \\
\text { record }\end{array}$ & $\begin{array}{c}\text { Mean } \\
\text { absolute } \\
\text { percent } \\
\text { error }\end{array}$ \\
\hline 18 & -- & Burns Creek 1 & 236 & -- & \\
\hline 19 & -- & Beaver Creek A5 & 355 & -- & \\
\hline \multirow[t]{2}{*}{20} & 06309075 & Sunday Creek near Miles City, Montana & 717 & 1975-84 & 69.4 \\
\hline & -- & North Sunday Creek 2 & 717 & -- & \\
\hline 21 & 06121500 & Lebo Creek near Harlowton, Montana ${ }^{1}$ & 54.6 & $\begin{array}{c}1909-11,1913, \\
1924-31\end{array}$ & 80.8 \\
\hline
\end{tabular}

${ }^{1}$ Seasonally operated USGS streamflow-gaging station. Fewer than 12 monthly mean streamflow values used in the analysis.

\section{Summary}

Estimating streamflow characteristics at ungaged fish sampling sites in central and eastern Montana included a series of steps. First, daily streamflow values were simulated using Precipitation-Runoff Modeling System (PRMS) models for baseline conditions (associated with water years [WYs] 1982-99) and for three future periods (associated with WYs 2021-38, 2046-63, and 2071-88) under two different potential future climate change scenarios for WYs 2021-38 (2030s) and 2071-88 (2080s) and three different potential future climate scenarios for WYs 2046-63 (2055s) at 179 nodes, or sites, throughout central and eastern Montana. Second, 89 streamflow characteristics (dependent variables) were derived from streamflow data. Third, drainage basins were delineated for the 179 PRMS nodes (fig. 2) and 1,707 fish sampling sites (fig. 3). These drainage basins were used to calculate 20 drainage basin characteristics (predictor variables) in ArcGIS. Fourth, 89 random forest (RF) regression models were developed using the 89 streamflow characteristics derived from streamflow data simulated for baseline conditions at the 179 PRMS nodes as dependent variables and the drainage basin characteristics associated with the PRMS nodes as predictor variables. These regression models were then used to predict values for the 89 streamflow characteristics for baseline conditions at the fish sampling sites using the drainage basin characteristics associated with the fish sampling sites. Fifth, $89 \mathrm{RF}$ regression predictive models were developed for each future period and potential future climate change scenario using the 89 streamflow characteristics derived from streamflow data simulated for the respective period and potential future climate change scenario. In total there were $712 \mathrm{RF}$ regression models developed ( 89 for baseline, or current, conditions and $623 \mathrm{RF}$ regression models from 7 different combinations of future periods and potential future climate change scenarios [ 2 for 2030s, 3 for 2055s, and 2 for 2080s]). Sixth, the RF regression models were used to estimate streamflow characteristics at the 1,707 fish sampling sites for each future period and potential climate change scenario

Model performance was assessed using the average root mean square error (RMSE), which was generated for each model based on internal cross validation of the RF regression model. The minimum average RMSE for all predictive models was about 33 percent. The maximum average RMSE for all predictive models was about 80 percent. The mean average RMSE for all predictive models was about 50 percent.

\section{References Cited}

Barnett, Tim; Malone, Robert; Pennell, William; Stammer, Detlet; Semtner, Bert; and Washington, Warren, 2004, The effects of climate change on water resources in the west - Introduction and overview: Climate Change, v. 62, no. 1, p. 1-11. [Also available at https://doi.org/10.1023/ B:CLIM.0000013695.21726.b8.]

Breiman, Leo, 2001, Random forests: Machine Learning, v. 45, no. 1, p. 5-32. [Also available at https://doi. org/10.1023/A:1010933404324.]

Chase, K.J., Haj, A.E., Regan, R.S., and Viger, R.J., 2016, Potential effects of climate change on streamflow for seven watersheds in eastern and central Montana: Journal of Hydrology—Regional Studies, v. 7, p. 1-13, https://doi. org/10.1016/j.ejrh.2016.06.001. 
Gesch, D.B., Oimoen, M.J., Greenlee, S.K., Nelson, C.A., Steuck, Michael, and Tyler, D.J., 2002, The National Elevation Dataset: Photogrammetric Engineering and Remote Sensing, v. 68, no. 1, p. 5-11.

Esri, 2014, ArcGIS for desktop (ver. 10.2): Redlands, Calif., Environmental Systems Research Institute, Inc., accessed June 2014 at http://www.esri.com/software/arcgis/arcgisfor-desktop.

Hanke, J.E., and Reitsch, A.G., 1995, Business forecasting (5th ed.): Englewood Cliffs, N.J., Prentice-Hall, 120 p.

Hay, L.E., and McCabe, G.J., 2010, Hydrologic effects of climate change in the Yukon River Basin: Climate Change, v. 100 , no. 3, p. 509-523. [Also available at https://doi. org/10.1007/s10584-010-9805-x.]

Helsel, D.R., and Hirsch, R.M., 2002, Statistical methods in water resources: U.S. Geological Survey Techniques of Water-Resources Investigations, book 4, chap. A3, 522 p. [Also available at https://pubs.usgs.gov/twri/twri4a3/.]

Homer, Collin; Dewitz, Jon; Fry, Joyce; Coan, Michael; Hossain, Nazmul; Larson, Charles; Herold, Nate; McKerrow, Alexa; VanDriel, J.N.; and Wickham, James, 2007, Completion of the 2001 National Land Cover Database for the conterminous United States: Photogrammetric Engineering and Remote Sensing, v. 73, no. 4, p. 337-341.

Horizon Systems Corporation, 2013, NHDPlusHome: Horizon Systems Corporation Web page, accessed June 2014 at http://www.horizon-systems.com/nhdplus.

Hostetler, S.W., Alder, J.R., and Allan, A.M., 2011, Dynamically downscaled climate simulations over North America-Methods, evaluation and supporting documentation for users: U.S. Geological Survey Open-File Report 2011-1238, 64 p. [Also available at https://pubs.usgs.gov/ of/2011/1238/.]

Leavesly, G.H., Lichty, R.W., Troutman, B.M., and Saindon, L.G., 1983, Precipitation-runoff modeling system-User's manual: U.S. Geological Survey Water-Resources Investigations Report 83-4238, 207 p. [Also available at https:// pubs.er.usgs.gov/publication/wri834238.]

Liaw, Andy, and Wiener, Matthew, 2002, Classification and regression by randomForest: R News, v. 2-3, p. 18-22.

McCarthy, P.M., 2016, Streamflow characteristics based on data through water year 2009 for selected streamflowgaging stations in or near Montana: U.S. Geological Survey Scientific Investigations Report 2015-5019-E, 10 p. [Also available at https://doi.org/10.3133/sir20155019E.]
Mu, Qiaozhen, Heinsch, F.A., Zhao, Maosheng, and Running, S.W., 2007, Development of a global evapotranspiration algorithm based on MODIS and global meteorology data: Remote Sensing of Environment, v. 111, no. 4, p. 519-536. [Also available at https://doi.org/10.1016/j. rse.2007.04.015.]

Natural Resources Canada, 2009, Land Cover, circa 2000Vector: Sherbrooke, Canada, Natural Resources Canada, GeoBase Web page, accessed December 2014 at http:// www.geobase.ca/geobase/en/data/landcover/csc2000v/ description.html.

Omang, R.J., 1992, Analysis of the magnitude and frequency of floods and the peak-flow gaging network in Montana: U.S. Geological Survey Water-Resources Investigations Report 92-4048, 70 p. [Also available at https://pubs. er.usgs.gov/publication/wri924048.]

Parrett, Charles, and Omang, R.J., 1981, Revised techniques for estimating magnitude and frequency of floods in Montana: U.S. Geological Survey Open-File Report 81-917, $66 \mathrm{p}$. [Also available at https://pubs.er.usgs.gov/publication/ ofr81917.]

Parrett, Charles, and Johnson, D.R., 2004, Methods for estimating flood frequency in Montana based on data through water year 1998: U.S. Geological Survey Water-Resources Investigations Report 03-4308, 101 p. [Also available at https://pubs.usgs.gov/wri/wri03-4308/.]

Prasad, A.M., Iverson, L.R., and Liaw, Andy, 2006, Newer classification and regression tree techniques-Bagging and random forests for ecological prediction: Ecosystems, v. 9, no. 2, p. 181-199. [Also available at https://doi.org/10.1007/ s10021-005-0054-1.]

PRISM Climate Group, 2015, PRISM climate data: Oregon State University, PRISM Climate Group Web page, accessed February 15, 2015, at http://prism.oregonstate.edu.

R Core Team, 2014, R-A language and environment for statistical computing: Vienna, Austria, R Foundation for Statistical Computing, accessed June 8, 2014, at https:// www.r-project.org/.

Sando, Roy, Sando, S.K., McCarthy, P.M., and Dutton, D.M., 2016, Methods for estimating peak-flow frequencies at ungaged sites in Montana based on data through water year 2011: U.S. Geological Survey Scientific Investigations Report 2016-5019-F, 30 p. [Also available at https://doi. org/10.3133/sir20155019F.]

Tasker, G.D., 1978, Relation between standard errors in log units and standard errors in percent: U.S. Geological Survey Water Resources Division Bulletin, January-March 1978, p. 86-87. 
Thornton, P.E., Thornton, M.M., Mayer, B.W., Wilhelmi, Nate, Wei, Yaxing, Devarakonda, Ranjeet, and Cook, R.B., 2012, Daymet - Daily surface weather on a $1 \mathrm{~km}$ grid for North America, 1980-2008: Oak Ridge, Tenn., Oak Ridge National Laboratory, Distributed Active Archive Center, accessed June 2014 at https://doi.org/10.3334/ORNLDAAC/1328.

U.S. Environmental Protection Agency, 2000, Water quality conditions in the United States - A profile form the 1998 national water quality inventory report to Congress: Washington, D.C., U.S. Environmental Protection Agency, EPA-841-F-00-006, 2 p. [Also available at https://www. epa.gov/sites/production/files/2015-09/documents/2000_06 _30_305b_98report_98summary.pdf.]
U.S. Geological Survey, 2014, USGS Water data for the Nation: U.S. Geological Survey, National Water Information System Web page, accessed August 30, 2014, at https:// doi.org/10.5066/F7P55KJN.

Wilkowske, C.D., Kenney, T.A., and Wright, S.J., 2008, Methods for estimating monthly and annual streamflow statistics at ungaged sites in Utah: U.S. Geological Survey Scientific Investigations Report 2008-5230, 63 p. [Also available at https://pubs.usgs.gov/sir/2008/5230.] 

Appendix 1 


\section{Appendix 1. Supplemental Information Relating to the Statistical Analysis}

Appendix 1 tables are available for download as a Microsoft Excel ${ }^{\circledR}$ file at https://doi.org/10.3133/sir20175002.

Table 1-1. Streamflow characteristics, in cubic feet per second, at Precipitation-Runoff Modeling System nodes calculated from data simulated by Chase and others (2016) for baseline conditions.

Table 1-2. Streamflow characteristics, in cubic feet per second, at Precipitation-Runoff Modeling System nodes calculated from data simulated by Chase and others (2016) for the ECHAM5 2030s scenario.

Table 1-3. Streamflow characteristics, in cubic feet per second, at Precipitation-Runoff Modeling System nodes calculated from data simulated by Chase and others (2016) for the ECHAM5 2055s scenario.

Table 1-4. Streamflow characteristics, in cubic feet per second, at Precipitation-Runoff Modeling System nodes calculated from data simulated by Chase and others (2016) for the ECHAM5 2080s scenario.

Table 1-5. Streamflow characteristics, in cubic feet per second, at Precipitation-Runoff Modeling System nodes calculated from data simulated by Chase and others (2016) for the GENMOM 2030s scenario.

Table 1-6. Streamflow characteristics, in cubic feet per second, at Precipitation-Runoff Modeling System nodes calculated from data simulated by Chase and others (2016) for the GENMOM 2055s scenario.

Table 1-7. Streamflow characteristics, in cubic feet per second, at Precipitation-Runoff Modeling System nodes calculated from data simulated by Chase and others (2016) for the GENMOM 2080s scenario.

Publishing support provided by:

Rolla Publishing Service Center

For more information concerning this publication, contact:

Director, Wyoming-Montana Water Science Center

U.S. Geological Survey

3162 Bozeman Ave

Helena, MT 59601

(406) 457-5900

Or visit the Wyoming-Montana Water Science Center website at:

https://wy-mt.water.usgs.gov/
Table 1-8. Streamflow characteristics, in cubic feet per second, at Precipitation-Runoff Modeling System nodes calculated from data simulated by Chase and others (2016) for the GFDL 2055s scenario.

Table 1-9. Drainage basin characteristic values for drainage basins associated with Precipitation-Runoff Modeling System nodes.

Table 1-10. Drainage basin characteristic values for drainage basins associated with fish sampling sites.

Table 1-11. Streamflow characteristics, in cubic feet per second, predicted at fish sampling sites for baseline conditions.

Table 1-12. Streamflow characteristics, in cubic feet per second, predicted at fish sampling sites for the ECHAM5 2030s scenario.

Table 1-13. Streamflow characteristics, in cubic feet per second, predicted at fish sampling sites for the ECHAM5 2055s scenario.

Table 1-14. Streamflow characteristics, in cubic feet per second, predicted at fish sampling sites for the ECHAM5 2080s scenario.

Table 1-15. Streamflow characteristics, in cubic feet per second, predicted at fish sampling sites for the GENMOM 2030s scenario.

Table 1-16. Streamflow characteristics, in cubic feet per second, predicted at fish sampling sites for the GENMOM 2055s scenario.

Table 1-17. Streamflow characteristics, in cubic feet per second, predicted at fish sampling sites for the GENMOM 2080s scenario.

Table 1-18. Streamflow characteristics, in cubic feet per second, predicted at fish sampling sites for the GFDL 2055s scenario. 

